Check for updates

Cite this: RSC Adv., 2020, 10, 13196

\title{
Chemisorption and sustained release of cefotaxime between a layered double hydroxide and polyvinyl alcohol nanofibers for enhanced efficacy against second degree burn wound infection $\uparrow$
}

\author{
Maha B. Abd Elhaleem, ${ }^{a}$ Ahmed A. Farghali, ${ }^{b}$ Ahmed. A. G. El-Shahawy, (D)*b \\ Fatma I. Abo El-Ela, ${ }^{c}$ Zienab E. Eldine ${ }^{b c}$ and Rehab Khalid Mahmoud ${ }^{a}$
}

Zn-Al layered double hydroxides (LDHs) were synthesized by a chemical method, while polyvinyl alcohol (PVA) nanofibers were fabricated by an electrospinning approach; we also synthesized $\mathrm{Zn}-\mathrm{Al}$ LDH/ cefotaxime (cefotax), Zn-Al LDHaPVA, and Zn-Al LDH/cefotax@PVA (LCP). Characterizations were performed by $\mathrm{X}$-ray diffraction, Fourier transform infrared spectroscopy, field emission scanning electron microscopy, high-resolution transmission electron microscopy, energy dispersive X-ray spectroscopy, Brunauer-Emmett-Teller analysis, thermogravimetric-differential thermal analysis techniques, dynamic light scattering, $\mathrm{X}$ ray-florescence, and carbon, hydrogen, and nitrogen (CHN) analyses. The adsorption isotherm of cefotax and its entrapment percentage, release, and kinetics were also investigated. The results confirmed the elemental constituents of the mentioned formulas, which exhibited different degrees of crystallinity and different morphologies. Besides, these formulas were tested in vitro as antimicrobial agents and applied in vivo against second-degree wound burns induced in rats' skin. The adsorption of cefotax occurred chemically, and the experimental data were fitted with different isotherm models, where the Freundlich and Toth models gave the best fits. The entrapment percentage in LDH/ cefotax was $77.41 \%$ and in LDH/cefotax@PVA, it was $67.83 \%$. The sustained release of cefotax from LDH and LCP was attainable; the release percentages were $89.31 \%$ and $81.55 \%$ in up to $12 \mathrm{~h}$, respectively. The release kinetics of cefotax from LDH fitted well with first-order kinetics, while that for LCP was parabolic. The formulas showed uneven antimicrobial effects against Gram-positive and Gram-negative bacteria; the best effect was exhibited by $\mathrm{Zn}-\mathrm{Al}$ LDH/cefotax@PVA due to its sustained release. Finally, investigating the possibility of using these formulas in the clinical setting should be considered.

Received 16th October 2019 Accepted 19th February 2020

DOI: $10.1039 / c 9 r a 08355 c$

rsc.li/rsc-advances affected are the epidermis and hypodermis $;^{6}$ the healing process of this degree is intricate and multistage and comprises inflammation, proliferation, neovascularization, reepithelialization, and wound contraction., ${ }^{7,8}$

It is essential to realize that burn wound infection is one of the factors that can lead to mortality and morbidity. ${ }^{9}$ Although the current antibiotics can substantially enhance the process of wound recovery, they cannot reach the infected area in their active form and at a sufficiently effective concentration; besides, they may incur some issues such as toxicity and resistance. Consequently, for antibiotics to be more efficient, their half-life should increase, and their dose above the minimum inhibition concentration of bacteria should be limited. It is well known that cefotax has significant antibacterial potential toward Grampositive and Gram-negative bacteria ${ }^{\mathbf{1 0}}$ and against various infections such as those of the respiratory tract, skin, joint, and bone. ${ }^{11}$ The short half-life of cefotax and the high resistance of $\beta$-lactamase against cefotax limit its use in clinical settings. ${ }^{12}$ To
${ }^{a}$ Chemistry Department, Faculty of Science, Beni-Suef University, Beni-Suef, Egypt. E-mail: mahabadawy36@gmail.com; radwaraft@yahoo.com

${ }^{b}$ Materials Science and Nanotechnology Dept., Faculty of Postgraduate Studies for Advanced Sciences (PSAS), Beni-Suef University, Beni-Suef, Egypt. E-mail: ahmed. elshahawy@psas.bsu.edu.eg; Ahmedfarghali74@yahoo.com; Tel: +20 226798209 'Pharmacology Department, Faculty of Veterinary Medicine, Beni-Suef University, 62511 Beni-Suef, Egypt.E-mail: fa.pharma@yahoo.com; Zienab_ryad@yahoo.com

$\dagger$ Electronic supplementary information (ESI) available. See DOI: $10.1039 / \mathrm{c} 9 \mathrm{ra} 08355 \mathrm{c}$ 
enhance the efficacy of cefotax, it is essential to control or to sustain its release at the site of infection.

Layered double hydroxides constitute a broad family of lamellar solids similar to anionic clay with a hydrotalcite structure. ${ }^{13}$ The structural formula of LDHs is $\left(\mathrm{M}^{2+}{ }_{1-x} \mathrm{M}^{3+}{ }^{-}\right.$ $\left.(\mathrm{OH})_{2}\right)_{x^{+}}\left[\mathrm{A}^{n-}\right]_{x / n} \cdot m \mathrm{H}_{2} \mathrm{O}$, where $\mathrm{M}^{2+}$ is a divalent cation, $\mathrm{M}^{3+}$ is a trivalent cation, and $\mathrm{A}^{n-}$ is an intercalated anion. ${ }^{\mathbf{1 4 1 5}}$ LDHs can intercalate biologically-active molecules through anion exchange, ${ }^{16,17}$ a property which has opened their applications in medicine and pharmacy ${ }^{\mathbf{1 8}}$ as drug carriers for many antibiotics, ${ }^{16,19}$ anti-inflammatory agents ${ }^{20}$ targeted drug delivery vehicles, ${ }^{21-23}$ and for wound healing. ${ }^{24}$ Recently, nanoparticles, beads, bandages, biofilms, and nanofibers have been considered intrinsic materials to attain sustained release. ${ }^{25}$ In particular, nanofibers are ideal candidates for wound dressing, because of their physical, mechanical, chemical properties, as well as high porosity, high surface to volume ratio, small pore size, and gas permeation properties. ${ }^{26}$ Besides, nanofibers are biocompatible, biodegradable, non-toxic, easily removed, and able to exchange gases and absorb excessed exudates of a wound.

Again, a primary concern of burn healing is the infection; in this respect, the target of the current study was to investigate the sustained release of cefotax and its kinetics against Grampositive and Gram-negative bacterial strains; particularly, in the infection related to a second degree burn. The study succeeded through loading cefotax on two different nano-formulas: cefotax-loaded Zn-Al LDH and cefotax-loaded LDH@PVA. The novelty of cefotax-loaded LDH@PVA was manifested in the choosing of PVA, which is a synthetic water-soluble hydrophilic polymer, for the nanofiber formation, where the hydroxyl groups of PVA were cross-linked with the aldehyde groups chemically forming nanofibers with insoluble membranes, and forming hydrogen bonding with the hydroxyl groups of cefotax and the LDH. The high adsorption ability of LDH enhanced the entrapment efficiency and stability against light degradation, which maintained the release of cefotax; besides, $\mathrm{Zn}$-Al hydrotalcite avoided skin reaction and supported removal of the inflammatory exudates. On the other hand, the LDHs are very sensitive when used as drug carrier in acidic media unless they are covered with a polymer film, which preserves them from degradation in acidic media; this is a field where new insights are still required and more research work needs to be undertaken. $^{20}$

\section{Materials and methods}

\subsection{Materials}

Zinc chloride $\left(\mathrm{ZnCl}_{2}\right)$ 97\% was purchased from LOBA Chemie, India; aluminum chloride hexahydrate $\left(\mathrm{AlCl}_{3} \cdot 6 \mathrm{H}_{2} \mathrm{O}\right) 98 \%$ from Alpha Chemika, India; hydrochloric acid $(\mathrm{HCl})$ and sodium hydroxide ( $\mathrm{NaOH})$ 98\% from Biochem for Laboratory Chemicals, Egypt. Cefotaxime sodium $\left(\mathrm{C}_{16} \mathrm{H}_{16} \mathrm{NaN}_{5} \mathrm{O}_{7} \mathrm{~S}_{2}\right) 100 \%$ purity (see Table 1$)^{27-30}$ and $95 \%$ difloxacin were purchased from Pharma Swede pharmaceutical company. A tube of MEBO, Vaseline, Grotto ointment, was purchased from Julphar, Egypt; each tube contained (15 g). Glutaraldehyde (GA) and polyvinyl alcohol (PVA) with $M_{\mathrm{w}}=115000 \mathrm{kDa}$ were purchased from
Oxford Lab Chem, India, and bidistilled water was used throughout the experiment. All these chemicals were used without any further purification.

\subsection{Synthesis of $\mathrm{Zn}-\mathrm{Al} \mathrm{LDH}$ and $\mathrm{Zn}-\mathrm{Al} \mathrm{LDH} /$ cefotax composite}

$\mathrm{Zn}$-Al LDH was prepared by the co-precipitation method as follows: a solution of $0.04 \mathrm{~mol}$ of $\mathrm{ZnCl}_{2}$ and $0.01 \mathrm{~mol}$ of $\mathrm{AlCl}_{3}$ $\cdot 6 \mathrm{H}_{2} \mathrm{O}$ (with a molar ratio of $4: 1$ ) was added to $100 \mathrm{~mL}$ bidistilled water with good mixing; then $\mathrm{NaOH}\left(1 \mathrm{~mol} \mathrm{~L}^{-1}\right)$ was added dropwise until a complete white precipitate was obtained at $\mathrm{pH}$ 9. The resulting suspension lasted under vigorous stirring at $50{ }^{\circ} \mathrm{C}$ for $24 \mathrm{~h}$, and the precipitate was collected, washed several times using bidistilled water and ethanol until $\mathrm{pH} 7$, and finally dried at $40{ }^{\circ} \mathrm{C}$ for $24 \mathrm{~h}^{24}$ The $\mathrm{Zn}-\mathrm{Al} \mathrm{LDH} /$ cefotax composite was synthesized by the aforementioned method with the same procedure. One difference was the ratio between the elemental constituents of the composite, whereby $\mathrm{NaOH}$ was added to a well-mixed solution of $0.04 \mathrm{~mol}$ of $\mathrm{ZnCl}_{2}$, $0.01 \mathrm{~mol}$ of $\mathrm{AlCl}_{3} \cdot 6 \mathrm{H}_{2} \mathrm{O}$, and $0.0006 \mathrm{~mol}$ of cefotax with a molar ration of $4: 1: 0.0625 \mathrm{ZnCl}_{2}: \mathrm{AlCl}_{3} \cdot 6 \mathrm{H}_{2} \mathrm{O}$ : cefotax, respectively. Fig. S1a \& $\mathrm{b} \dagger$ display the elemental configuration of the prepared $\mathrm{LDH}$ and $\mathrm{LDH} /$ cefotax.

\subsection{Synthesis of the polymeric cross-linked PVA nanofibers}

A concentration $(10 \mathrm{wt} \%)$ of the PVA water solution was prepared by stirring at $90{ }^{\circ} \mathrm{C}$ for $4 \mathrm{~h}$. For the cross-linking reaction, $0.25 \%$ GA was added to the PVA solution under continuous stirring at $60{ }^{\circ} \mathrm{C}$ for $2 \mathrm{~h}$. Then, the cross-linked polymeric solution was loaded into a plastic syringe $(10 \mathrm{~mL})$, and electrospun at an applied voltage of $18 \mathrm{KV}$ to form the polymeric nanofibers. The solution was constantly supplied using a syringe pump at a flow rate of $0.7 \mathrm{~mL} \mathrm{~h}^{-1}$, and the spinning distance between the needle and the ground electrode was $14 \mathrm{~cm} .^{31}$

\subsection{Synthesis of Zn-Al LDH@PVA and Zn-Al LDH/cefotax (aPVA nanofibers}

For the Zn-Al LDH@PVA nanofibers, $0.1 \mathrm{~g}$ of the prepared $\mathrm{Zn}-\mathrm{Al}$ LDH was added into $10 \mathrm{~mL}$ of the PVA cross-linked viscous solution with continuous stirring at $50{ }^{\circ} \mathrm{C}$ for $1 \mathrm{~h}$, and the electrospinning procedures were conducted as mentioned. For the $\mathrm{Zn}-\mathrm{Al}$ LDH/cefotax @PVA nanofibers, the same process as outlined in Scheme 1 was performed. ${ }^{32}$

\subsection{Characterization study}

The prepared materials were characterized as follow: the crystallinity was analyzed using an X-ray diffraction (XRD) system (PANalytical Empyrean, 202964, Sweden) with $\mathrm{Cu} \mathrm{K} \alpha$ radiation $\left(\lambda=0.154 \mathrm{~cm}^{-1}\right)$, at an accelerating voltage of $40 \mathrm{kV}$, current of $35 \mathrm{~mA}$, scan angle of $5-80^{\circ}$ and with a scan step of $0.04^{\circ}$. Analysis of the functional groups was performed utilizing a Fourier transform infrared (FTIR) spectroscopy system (Bruker-Vertex 70, KBr pellet technique, Germany), over the range of $400-4000 \mathrm{~cm}^{-1}$. The morphology and structure were 
Table 1 Cefotax

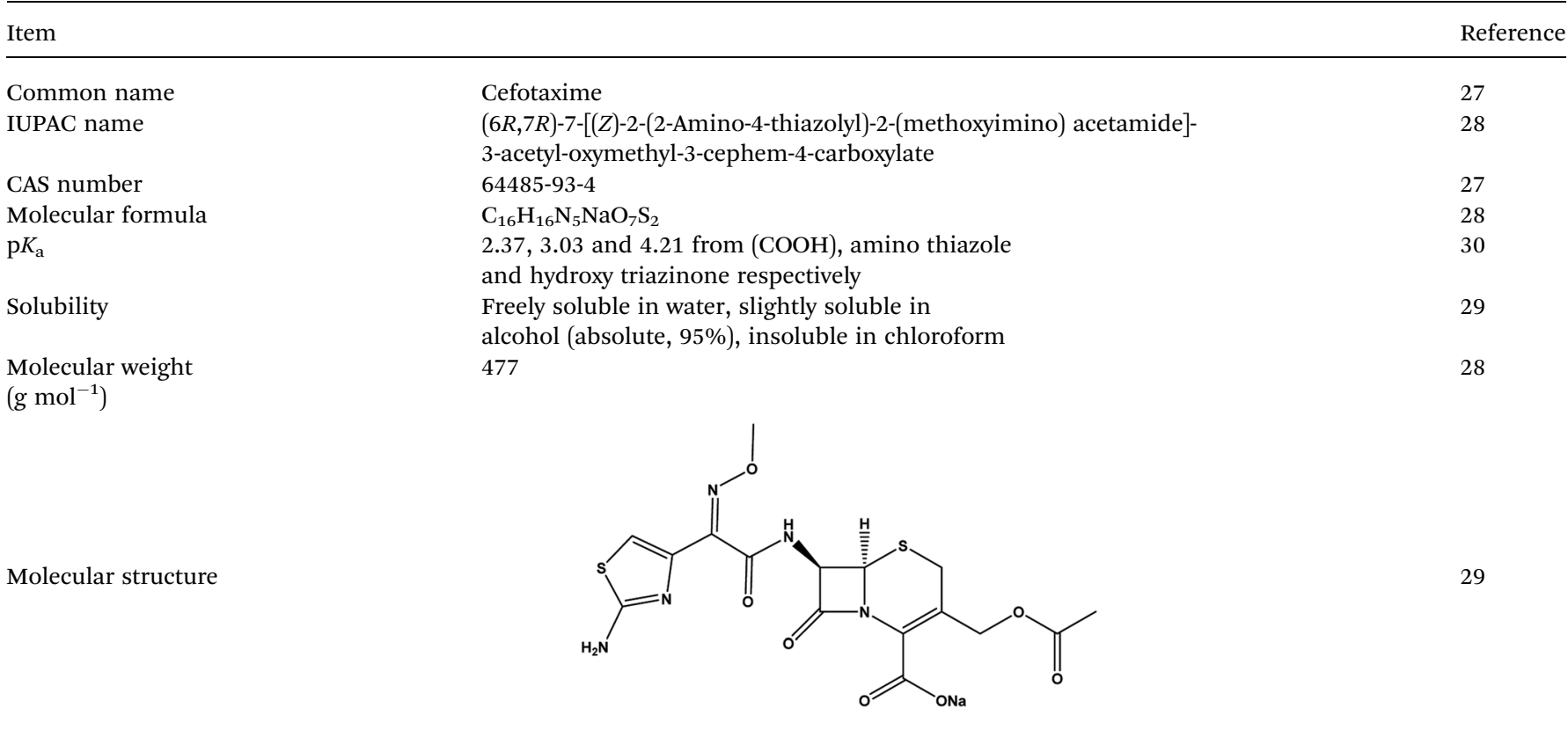

analyzed by field emission scanning electron microscopy (FESEM, JEOL JSM-5900, Japan) and high-resolution transmission electron microscopy (H-RTEM JEOL JEM-2100, USA) with an acceleration voltage of $200 \mathrm{KV}$.

The elemental analysis of $\mathrm{Zn}-\mathrm{Al} \mathrm{LDH}$ was performed by energy dispersive X-ray spectroscopy (EDX, Quanta FEG-250, Germany), while the composition of $\mathrm{Zn}-\mathrm{Al} \mathrm{LDH} /$ cefotax was determined using elemental CHNS analysis (Vario, EL III analyzer), and $\mathrm{X}$ ray-florescence spectroscopy (XRF). The thermal stability was assessed by thermogravimetric differential thermal analysis (TGA-DTA) (Shimadzu Co. Tokyo, Japan); here, a sample of $50 \mathrm{mg}$ of the tested formula was heated up to $1000{ }^{\circ} \mathrm{C}$ at a rate of $20{ }^{\circ} \mathrm{C} \mathrm{min}{ }^{-1}$ under a dynamic $\mathrm{N}_{2}$ atmosphere. The specific surface areas, specific pore volume, and pore-size distribution were measured with $\mathrm{N}_{2}$ adsorption isotherms and an automatic surface analyzer (TriStar II 3020, Micromeritics, USA) according to the Brunauer-Emmett-Teller (BET) theory. The zeta potential and hydrodynamic diameter were determined by dynamic light scattering (DLS) with a zetasizer analyzer (Nano-ZS90, Malvern Instrument Ltd, United Kingdom).

\subsection{Adsorption experiments and percentage entrapment efficiency}

The adsorption isotherms experiments were performed in $250 \mathrm{~mL}$ conical flasks as follows: Serial dilutions of cefotax $\left(30,50,100,150,200,250 \mathrm{mg} \mathrm{L}^{-1}\right)$ were prepared from a cefotax stock solution (250 ppm), where these concentrations represent the initial concentration of cefotax before adsorption $\left(\mathrm{C}_{0}\right)$. Then, $0.1 \mathrm{~g}$ of $\mathrm{Zn}-\mathrm{Al} \mathrm{LDH}$ was added to a constant volume $(50 \mathrm{~mL})$ of each dilution at $\mathrm{pH}$, which was adjusted using a $\mathrm{pH}$ meter (Adwa-AD1030) by adding $0.1 \mathrm{M} \mathrm{HCl}$ and $0.1 \mathrm{M} \mathrm{NaOH}$. All the solutions were left for shaking on an orbital shaker (SK0330-pro) at a speed of $200 \mathrm{rpm}$ at room temperature for $24 \mathrm{~h}$. Next, Zn-Al LDH- loaded with cefotax from each initial dilution was separated by filtering through a syringe filter with a $0.22 \mu \mathrm{m}$ pore size (Millipore Millex-G, Hydrophilic PVDF), and the residual concentration of cefotax (where $C_{t}$ is the concentration of cefotax after adsorption at time $t$ min) was measured with a UV-Visible spectrophotometer (UV-2600, Shimadzu, Japan) at $250 \mathrm{~nm}$.

The efficiency of cefotax adsorption on $\mathrm{Zn}-\mathrm{Al} \mathrm{LDH}$ was calculated according to the following eqn (1):

$$
Q=\frac{\left(C_{0}-C_{t}\right)}{C_{0}} \times 100
$$

where $Q$ is the adsorptivity (\%), $C_{0}$ is the initial concentration of cefotax in $\mathrm{mg} \mathrm{L}^{-1}$, and $C_{t}$ is the concentration of cefotax after adsorption at time $t(\min )$. The amount of the adsorbed cefotax at equilibrium $q_{\mathrm{e}}\left(\mathrm{mg} \mathrm{g}^{-1}\right)$ was calculated through eqn (2):

$$
q_{\mathrm{e}}=\frac{V\left(C_{0}-C_{\mathrm{e}}\right)}{W}
$$

where $q_{\mathrm{e}}$ is the equilibrium adsorption capacity of the adsorbent by $\mathrm{mg} \mathrm{g}^{-1}$, while $C_{\mathrm{e}}$ is the equilibrium concentration of cefotax according to the volume of the cefotax solution in liters, and $W$ stands for the adsorbent ( $\mathrm{Zn}-\mathrm{Al} \mathrm{LDH})$ weight by the gram.

For calculation of the entrapped cefotax (\% entrapment efficiency), the separated $\mathrm{Zn}$-Al LDH-loaded with cefotax was centrifuged, and the concentration of the free cefotax (supernatant) was determined as mentioned. The percentage entrapment efficiency was calculated as follows according to eqn (3): 


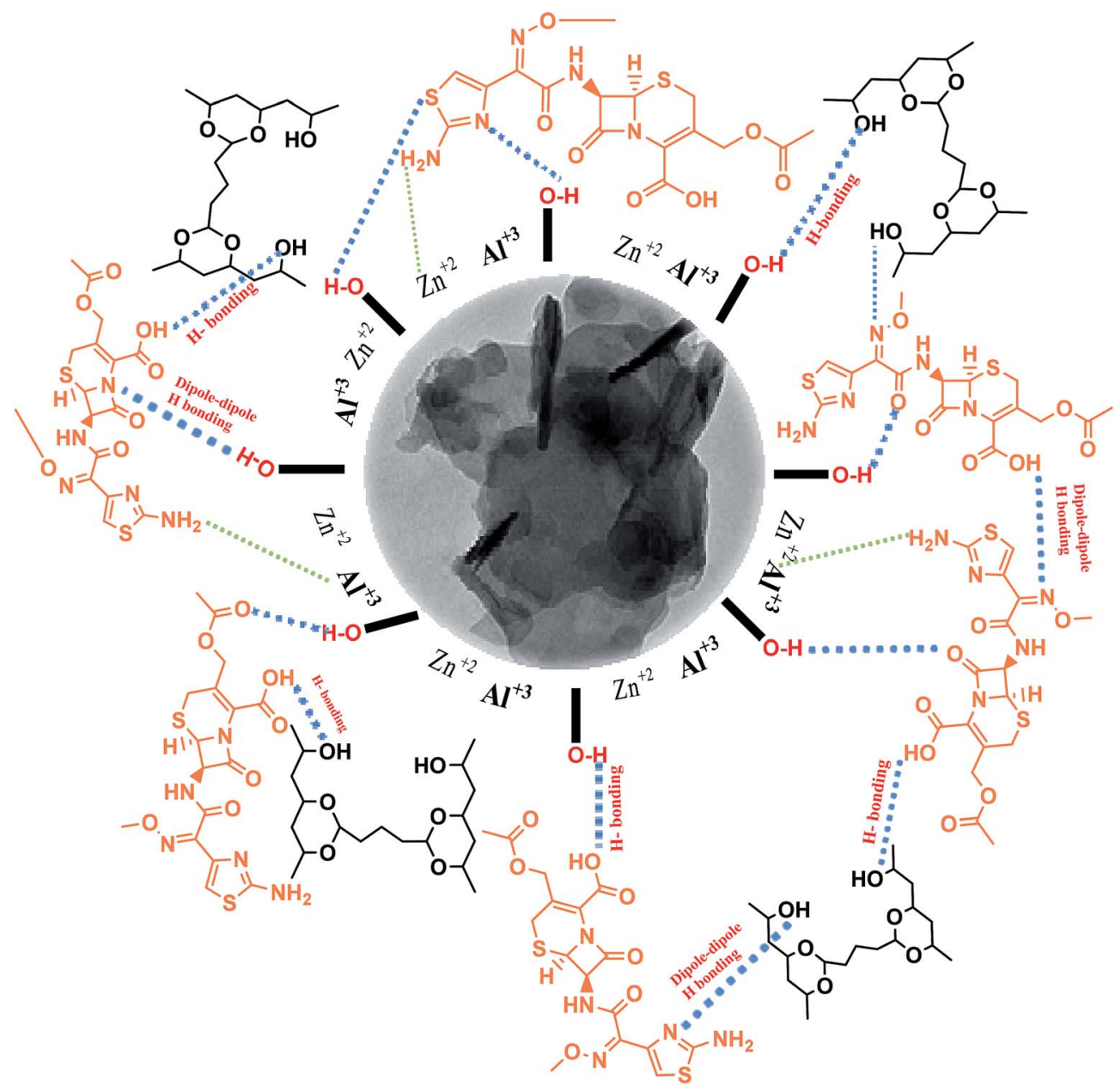

Scheme 1 The idea involved loading cefotax on two different nanoformulas: cefotax-loaded Zn-Al LDH and cefotax-loaded LDHaPVA nanofibers to sustain its release at the site of infection. Rearrangement of $\mathrm{Zn} / \mathrm{Al}$ ions, and partial replacement of chloride ions by cefotax molecules or by the adsorption of cefotax molecules on the surface of LDH occurred via hydrogen bonding; in light of the mentioned, it can be said that the likelihood of cefotax loading and even the partial intercalation between LDH, PVA, and cefotax was evidenced. The slow release of cefotax was achieved by the restriction of cefotax between LDH and PVA by hydrogen bond, dipole-dipole interaction, as well electrostatic force. The formulas were tested in vitro as antimicrobial agents, and applied in vivo against second degree wound burns induced in rats' skin.

\section{$\%$ Entrapment efficiency $=$}

total cefotax amount - free cefotax amount total cefotax amount

To ascertain the experimental reproducibility, all the experiments were conducted in triplicate, and the average concentration was determined using SPSS version 16. The mean and standard deviation $( \pm \mathrm{SD})$ values were computed, and $p$ values less than 0.05 were considered as statistically significant. All the preceding steps and equations involved use of the LCP formula.

\subsection{Cefotax release and kinetics study}

The cefotax release experiment of $\mathrm{Zn}-\mathrm{Al} \mathrm{LDH} /$ cefotax was conducted by monitoring the time-dependent release of cefotax molecules as follows: $1 \mathrm{mg}$ of cefotax-loaded LDH (which contained the calculated adsorbed cefotax at equilibrium, eqn (2)) was dispersed in $10 \mathrm{~mL}$ of phosphate buffer saline (PBS) solution at pH 5.6 and $37^{\circ} \mathrm{C}$. Under continuous stirring, and at a constant interval time $(100,200,300,400,500,600 \mathrm{~min}), 1 \mathrm{~mL}$ PBS solution was withdrawn and replaced by $1 \mathrm{~mL}$ of fresh PBS to maintain the concentration gradient of the PBS solution. The concentration of the released cefotax within the withdrawn sample was determined as mentioned. The experiment was conducted in triplicate, and the average concentration was determined. To understand the cefotax release kinetics, the cefotax release profile was fitted according to the first-order and parabolic diffusion kinetic models. Again, all the preceding steps involved use of the LCP formula.

\subsection{Animal preparation and burn induction}

The Institutional Animal Care and Committee of Beni-Suef University, Egypt, approved all the conducted procedures. All the animal handling, study procedures, weighting, dosing, and burns induction and treatment were approved according to the Guidelines for Care and Use of Laboratory Animals of the 
Faculty of Veterinary Medicine, Beni-Suef University, also according to the Institutional Animal Care and Ethical Committee of Beni-Suef University, Egypt. Burn induction and healing activity were as follows, ${ }^{33}$ in brief, a total of 30 male albino rats (350-400 g, 6-8 weeks old) were anesthetized through an intraperitoneal injection of ketamine $5 \%$ (90 $\mathrm{mg} \mathrm{kg} \mathrm{kg}^{-1} \mathrm{~B} \mathrm{wt}$ ), and xylazine hydrochloride $2 \%$ ( $5 \mathrm{mg} \mathrm{kg}^{-1} \mathrm{~B} \mathrm{wt}$ ), and then a surgical incision of $(20 \times 20 \mathrm{~mm})$ was induced on the back shaved area of the mice $(20 \times 20 \mathrm{~mm})$. Next, a stainless-steel, cone-shaped device with a diameter of $2 \mathrm{~cm}$ and weighing $400 \mathrm{~g}$ was heated to $100{ }^{\circ} \mathrm{C}$ and placed locally for $5 \mathrm{~s}$.

2.8.1. Experimental design. According to the appropriate hygienic and regulated conditions, and after $2 \mathrm{~h}$ of burn induction, all the tested formulas were prepared in a dosage form of an ointment of vaseline and a fiber-based formulation with the concentration of $10 \%$ and were applied topically on the burned area once daily until complete healing occurred. According to the assessed formula, the rats were divided into six categorizes as follows: G1 (Mat/LDH-Cefotaxime MLC), G2 (Mat/LDH), G3, (Mat only), G4 (Grotto ointment), G5 (Standard MEBO ointment), G6 (Control negative-Vaseline only).

All the rats were monitored daily, and any burn fluid or evidence of infection or other abnormalities were noted and recorded. The burn-healing activity was assessed by the burn contraction percentage and closure time. The burn size was measured at 4, 8, 12, 16, and 21 days post-operation, and the burn-healing percentage was calculated by the Walker formula ${ }^{34}$ as per eqn (4):

$$
\text { Percentage of wound size }=\frac{\text { wound area on day } X}{\text { wound area on day zero }} \times 100
$$

2.8.2. Wound healing evaluation. The wound healing was checked daily for three weeks by assessing for macroscopic signs of inflammation (hotness, redness, swelling, and reepithelization), an edema of about $4 \mathrm{~mm}$, and according to the gross morphology of the wounds in terms of color and margin, besides necrosis of the epithelial and connective tissues. Further, assessment was made through rulermeasurement of the wound size immediately after burn infliction every four days till day 21.

Moreover, microscopic assessment by histopathology was performed. All the rats were euthanized at the end of the experiment using a mix of ketamine and xylazine with a $1: 1$ ratio at a dose of $0.1 \mathrm{~mL} / 100 \mathrm{~g}$. The sample specimens were excised from the deepest area of the burn and were preserved in $10 \%$ formalin for $72 \mathrm{~h}$ at room temperature. For the histopathology, $4 \mu \mathrm{m}$ thick serial sections were cut using a rotary microtome (Microm HM350) equipped with a waterfall-based section transfer system (STS, Microm). The sections were stained with hematoxylin \& eosin and investigated. The condition of the epidermis, dermis, and subcutaneous fat and skeletal muscle were taken into account for evaluation.

2.8.3. Antibacterial study. The antimicrobial activity of the aforementioned synthesized materials was tested versus strains of Gram-positive bacteria (S. aureus, ATCC 25913) and (Bacillus
ATCC 6633) and Gram-negative bacteria (Pseudomonas ATCC 27853) and (E. coli, ATCC 25922). The inhibition zone diameters of all the tested bacteria were determined by the disc diffusion method; this method was done according to CLSI guidelines. In this context, sterilized discs of PVA-tested material with different sizes $(1,0.5,0.25,0,06$, and $0.125 \mathrm{~mm})$ were obtained and were placed on separate sterilized Mueller-Hinton agar plates; each plate comprised a specific and aseptically diffused strain of the mentioned bacteria. Then, all the plates were incubated at $37{ }^{\circ} \mathrm{C}$ for $24 \mathrm{~h}$. All the readings of the inhibition zones were taken in triplicate. In the same way, all the procedures were repeated with LDH@PVA, LDH/cefotax@PVA, cefotax, $\mathrm{LDH} /$ cefotax, and $\mathrm{LDH}$. It is worth mentioning that the antibacterial activity of these materials was compared with a purity of $95 \%$ of the difloxacin standard drug $\left(1000 \mu \mathrm{g} \mathrm{mL}^{-1}\right)$.

Further, the broth dilution method was implemented to estimate the minimum inhibitory concentration (MIC) of the cefotax, and of the synthesized nanomaterial $\mathrm{Zn}-\mathrm{Al} \mathrm{LDH} /$ cefotax in the presence of both a positive control (cefotax or $\mathrm{Zn}-\mathrm{Al} \mathrm{LDH}$ / cefotax without bacterial culture) and negative control (bacterial cell culture without cefotax or $\mathrm{Zn}-\mathrm{Al} \mathrm{LDH} /$ cefotax). For the MIC study, a specific bacterial colony count through matching with

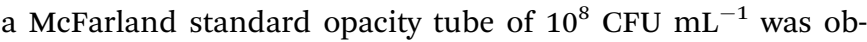
tained using sterile physiological saline, as previously mentioned. ${ }^{35}$ For each bacteria tested, a suspension of McFarland $100 \mu \mathrm{L}\left(10^{4} \mathrm{CFU}\right)$ in Muller-Hinton broth media was placed in different sterilized tubes containing a twofold serial dilution of the tested material (cefotax and $\mathrm{Zn}-\mathrm{Al} \mathrm{LDH} /$ cefotax). The results were recorded in terms of the MIC, which is the lowest concentration of the antimicrobial agent that inhibits growth. Equally important, the minimum bactericidal concentration (MBC) of those materials was detected. In the $\mathrm{MBC}$ experiments, a loopful from the MIC tubes of each tested material with two or more different concentrations of that material were placed on Muller-Hinton agar plates containing the tested bacteria. The concentration of the tested material that caused complete bactericidal inhibition of the bacterial growth after $24-48 \mathrm{~h}$ incubation at $37^{\circ} \mathrm{C}$ was considered as the MBC.

\section{Results and discussion}

\subsection{Material characterization}

3.1.1. X-ray diffraction. Fig. 1 displays the XRD patterns of the formed materials. Overall, Fig. 1a indicates the unique characteristic peaks of a layered double hydroxide, either at a low $2 \theta$ angle with basal peaks at (003) and (006) or high $2 \theta$ angle at the (101), (015), (018), (012), (110) and (113) planes, in agreement with ref. 36. Especially, the peak of (003) was evidence of the basal reflection of the interlayer anion in the $\mathrm{Zn}$ $\mathrm{Al} \mathrm{LDH}$ material, since that peak positioned at $2 \theta=11.31^{\circ}$ may be attributed to the reflection of a hydroxyl $(\mathrm{OH})$ or carbonate $\left(\mathrm{CO}_{3}\right)^{2-}$ as a form of $\mathrm{LDH} .{ }^{37}$ In addition, the peak cited at $36.2^{\circ}$ revealed an additional phase of $\mathrm{ZnO}$ along with $\mathrm{LDH}^{38}$ The image of the selected area electron diffraction pattern (SAED) shown in Fig. $3 \mathrm{~g}$ matched well with the XRD data and confirmed the high crystallinity of the prepared LDH. 


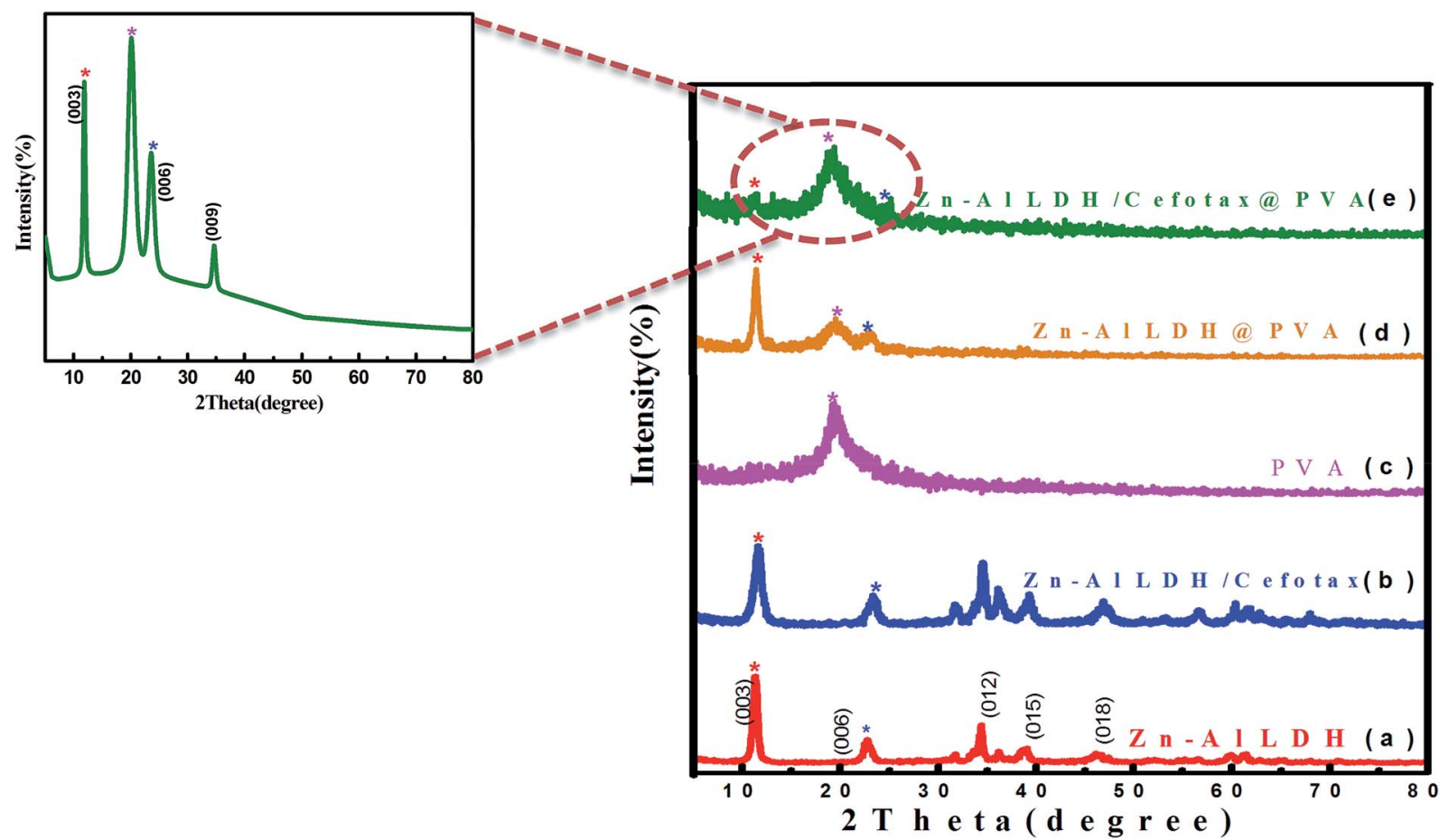

Fig. 1 XRD patterns of the prepared materials.

It was worth noting the similarity between the XRD result of $\mathrm{Zn}-\mathrm{Al} \mathrm{LDH}$ and that of $\mathrm{Zn}-\mathrm{Al} \mathrm{LDH} /$ cefotax shown in (Fig. 1b), in particular, the peaks marked with asterisks. However, some alterations were important to consider, for instance, the peak shifting to a high diffraction angle, the change in the relative intensity, and the broadening of the diffraction peaks. These alterations implied cefotax loading on LDH. Besides, the basal spacing of the (003) plane decreased from $7.82271 \AA$ in the case of LDH to $7.58808 \AA$ in Zn-Al LDH/cefotax, which revealed a less effective penetration of cefotax into the $\mathrm{Zn}-\mathrm{Al} / \mathrm{LDH}$ interlayers. ${ }^{39-41}$ This diminishing may refer to one of the following reasons: the removal of water molecules, rearrangement of $\mathrm{Zn} /$ $\mathrm{Al}$ ions, and partial replacement of chloride ions by cefotax molecules or the adsorption of cefotax molecules on the surface of LDH via hydrogen-bonding, ${ }^{42}$ as per the scheme submitted. Also, the d003 of the LDH and LDH/cefotax Nano composite was double that of d006 signifying a good layer structure. ${ }^{43}$ Fig. 1c exhibits the main characteristic peak for PVA nanofibers centered at $2 \theta=19.5^{\circ} .^{44,45}$ It should be noted the obvious resemblance between the mentioned patterns and that of LDH@PVA (Fig. 1d), as well as the (Fig. 1e) LDH/cefotax@PVA nanohybrid, especially, the peaks at (003) and (006), which showed a good resemblance. In light of the aforementioned, it can be said that the likelihood of cefotax loading and even the partial intercalation between LDH, PVA, and cefotax was evidenced..$^{32,46}$

3.1.2. Fourier transformation infra-red spectroscopy. It is important to recognize the structural alterations through the functional groups, and therefore we obtained the FTIR spectra, and these are presented in Fig. 2. Fig. 2, spectrum a shows the FTIR spectrum of $\mathrm{Zn}-\mathrm{Al} \mathrm{LDH}$, where the broad peak at
$3454 \mathrm{~cm}^{-1}$ is attributed to $\mathrm{O}-\mathrm{H}$ vibrations of $\mathrm{H}_{2} \mathrm{O}$ molecules and hydrogen bonding in $-\mathrm{OH}$ interlayer groups and a bending vibration at $1620 \mathrm{~cm}^{-1}{ }^{47,48}$ The intense peak at $1365 \mathrm{~cm}^{-1}$ reflected the symmetric and asymmetric stretching vibrations of a carbonate $\left(\mathrm{CO}_{3}\right)^{2-}$, which may be formed during the sample preparation process. ${ }^{37}$ The peaks that appeared below $700 \mathrm{~cm}^{-1}$ belonged to $\mathrm{M}-\mathrm{O}$ bond stretching and brucite lattice bending. ${ }^{49}$

Regarding LDH/cefotax, Fig. 2, spectrum b and inset (i) show the appearance of important bands of cefotax in the spectra of the $\mathrm{Zn}-\mathrm{Al} \mathrm{LDH} /$ cefotax composite as follows: stretching of $\mathrm{O}-\mathrm{H}$ groups appeared at $3456 \mathrm{~cm}^{-1}, \mathrm{~N}-\mathrm{H}$ stretching is shown around $1569 \mathrm{~cm}^{-1}, \quad \mathrm{C}=\mathrm{O}$ stretching vibration of $(\mathrm{COO})^{2-}$ at $1852.76 \mathrm{~cm}^{-1}$, the peaks at $1623,1494.10,1367.96,1032,772$, and $610 \mathrm{~cm}^{-1}$ are due to the presence of $\mathrm{C}=\mathrm{O}$ of an amide group, $\mathrm{N}-\mathrm{H}, \mathrm{C}=\mathrm{O}, \mathrm{C}-\mathrm{N}, \mathrm{C}-\mathrm{O}, \mathrm{CH}_{2}$, and $\mathrm{C}-\mathrm{S}$ groups, respectively. ${ }^{50}$ Two clear pieces of evidence demonstrated the successful loading of cefotax on the $\mathrm{Zn}-\mathrm{Al}$ LDH host: the appearance of cefotax bands and the difference between the two spectra, which was obvious and manifested in peaks shifting toward high wavenumbers, including the $-\mathrm{OH}$ group peak at $3454 \mathrm{~cm}^{-1}$ shifted to $3456.87 \mathrm{~cm}^{-1}$, the bending vibration of $\mathrm{OH}$ peak at $1620 \mathrm{~cm}^{-1}$ shifted to $1623.04 \mathrm{~cm}^{-1}$ denoting the promotion of hydrogen bonding interactions between $\mathrm{Zn}-\mathrm{Al}$ $\mathrm{LDH}$ and cefotax, ${ }^{24} \mathrm{C}=\mathrm{O}$ at $1365.67 \mathrm{~cm}^{-1}$ shifted to $1367.96 \mathrm{~cm}^{-1}$, and the $\mathrm{M}-\mathrm{O}$ bond stretching at 692 shifted to $610 \mathrm{~cm}^{-1}$.

In respect of PVA, Fig. 2, spectrum c exposed a broad and characteristic band of PVA at $3309 \mathrm{~cm}^{-1}$, while the peaks at 2925 and $1087 \mathrm{~cm}^{-1}$ were related to symmetrical and asymmetrical vibrations corresponding to $\mathrm{CH}_{2} \cdot{ }^{51-53} \mathrm{It}$ is important to be aware that adding GA as a cross-linker formed an acetal bridge 


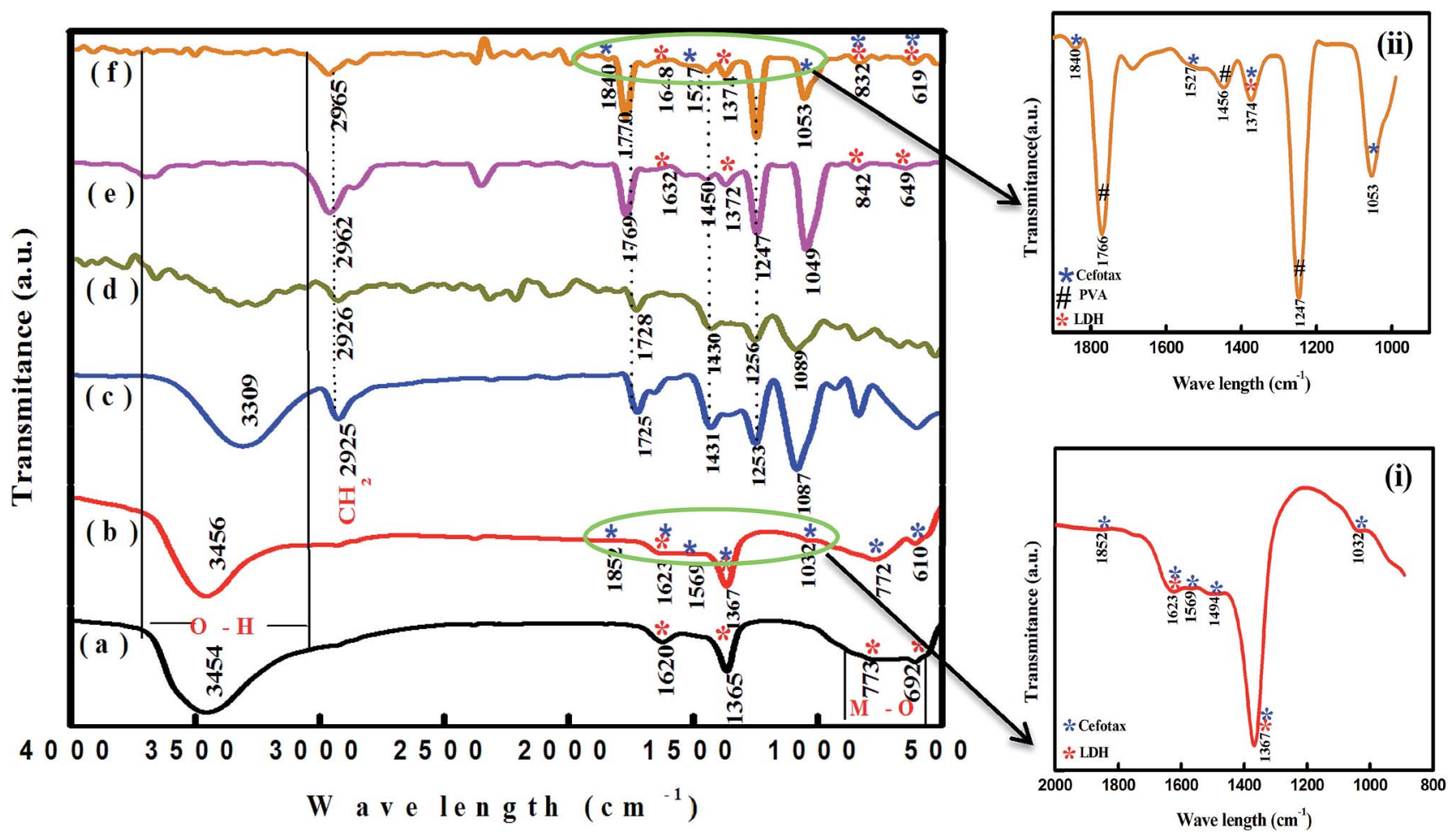

Fig. 2 FTIR spectra of (a) Zn-Al LDH, (b) Zn-Al LDH/cefotax, (c) PVA, (d) cross-linked PVA, (e) Zn-AL LDH@PVA, and (f) Zn-Al LDH/cefotax@PVA.

between the polymer (PVA) and GA, which in turn decreased the intensity of the PVA OH group intensity in Fig. 2 in spectra d, e, and $\mathrm{f}^{54}$ Besides, Fig. 2, spectrum e revealed an increase in the intensity of $\mathrm{C}=\mathrm{O}$ of PVA and a shift of the $\mathrm{CH}_{2}$ peak from 2926 to $2962 \mathrm{~cm}^{-1}$, which may be attributed to the interaction between PVA, GA, and LDH.

Concerning, Zn-Al LDH/cefotax @PVA (LCP), Fig. 2, spectrum $\mathrm{f}$ and inset (ii) exhibited the characteristic bands of $\mathrm{Zn}-\mathrm{Al}$ $\mathrm{LDH}, \mathrm{Zn}-\mathrm{Al} \mathrm{LDH} /$ cefotax, and PVA, demonstrating the configuration of the nanocomposite. Again, the observed variance among the FTIR spectra signalized the interaction between the synthesized materials, which matches with the XRD data.

In spite of its low binding energy, the great importance of the hydrogen bond stems from its effects on the physical and chemical properties of the material, and is related to the degree of crystallinity, the regularity of the crystal system, and the amount of adsorbed water molecules bound. ${ }^{55,56}$ In general, a decrease in the intensity or a disappearance of a band involved in the H-bond interactions means that this interaction is an 'intermolecular' one, and vice versa for 'intramolecular' interactions. The formation of intramolecular hydrogen bonding did not show any shift in absorption upon dilution, while the intermolecular did. Consequently, from the overview of spectra a-f in Fig. 2, the FTIR study evidenced the intramolecular hydrogen bonding among the LDH/cefotax/PVA entities, as per Scheme 1 . The calculated hydrogen bond intensity was the ratio of the absorbance bands at 3454 and $3456 \mathrm{~cm}^{-1}$ (for the $-\mathrm{OH}$ peak) and 1365.67 and $1367.69 \mathrm{~cm}^{-1}$ (for the $\mathrm{C}=\mathrm{O}$ peak) in $\mathrm{Zn}-$ $\mathrm{Al} \mathrm{LDH}$ and $\mathrm{Zn}-\mathrm{Al} \mathrm{LDH} /$ cefotax respectively. The absorbance ratio showed an increase in the case of $\mathrm{Zn}-\mathrm{Al} \mathrm{LDH} /$ cefotax nanocomposite (0.9709) more than that of Zn-Al LDH (0.807), indicating the hydrogen bonding interaction between the LDH and the loaded cefotax. ${ }^{42}$

3.1.3. Microscopic study FESEM and TEM. The FESEM study was crucial to indicate the morphology of the prepared materials.

Fig. 3a presents the FESEM image of Zn-Al LDH, revealing accumulated layers in a form of a lamellar or sheet structure, thus reflecting the good preparation of $\mathrm{LDH}$, which was in good agreement with ref. 57 and 58. Further, Fig. 3a shows the pore distribution (white arrow) with various volumes and sizes. Fig. $3 \mathrm{~b}$ illustrates the FESEM image of $\mathrm{Zn}-\mathrm{Al} \mathrm{LDH} /$ cefotax with a spherical and lamellar morphology. The formed PVA nanofibers (Fig. 3c) seemed to be cross-linked with a thick, smooth, and uniform surface, as well occurring in random directions without any aggregation, implying that the factors in the electrospinning method were well-controlled during the preparation, which gave results consistent with previous results. ${ }^{59,60}$ Fig. 3d exhibits the FESEM image of Zn-Al LDH@PVA nanofibers with decreased diameters $(99.49 \mathrm{~nm})$ compared with the diameters of the PVA nanofibers $(124.1 \mathrm{~mm})$ in Fig. S2. $\dagger$ The reasons attributed to the good dispersion of LDH in the PVA polymer solution include the change in solution electrical conductivity, viscosity, and surface tension, as reported also in the literature. ${ }^{61,62}$ Consequently, the condensation of the $\mathrm{Zn}-\mathrm{Al}$ LDH@PVA matrix was low compared with that of PVA, as shown in Fig. 3d. The acquired images resembled those given in ref. 63 and 64. Fig. 3e shows a compacted structure of the fibers with uniform diameters, as well as a uniform distribution of LDH/ cefotax over the nanofibers surface, either inner or outer 

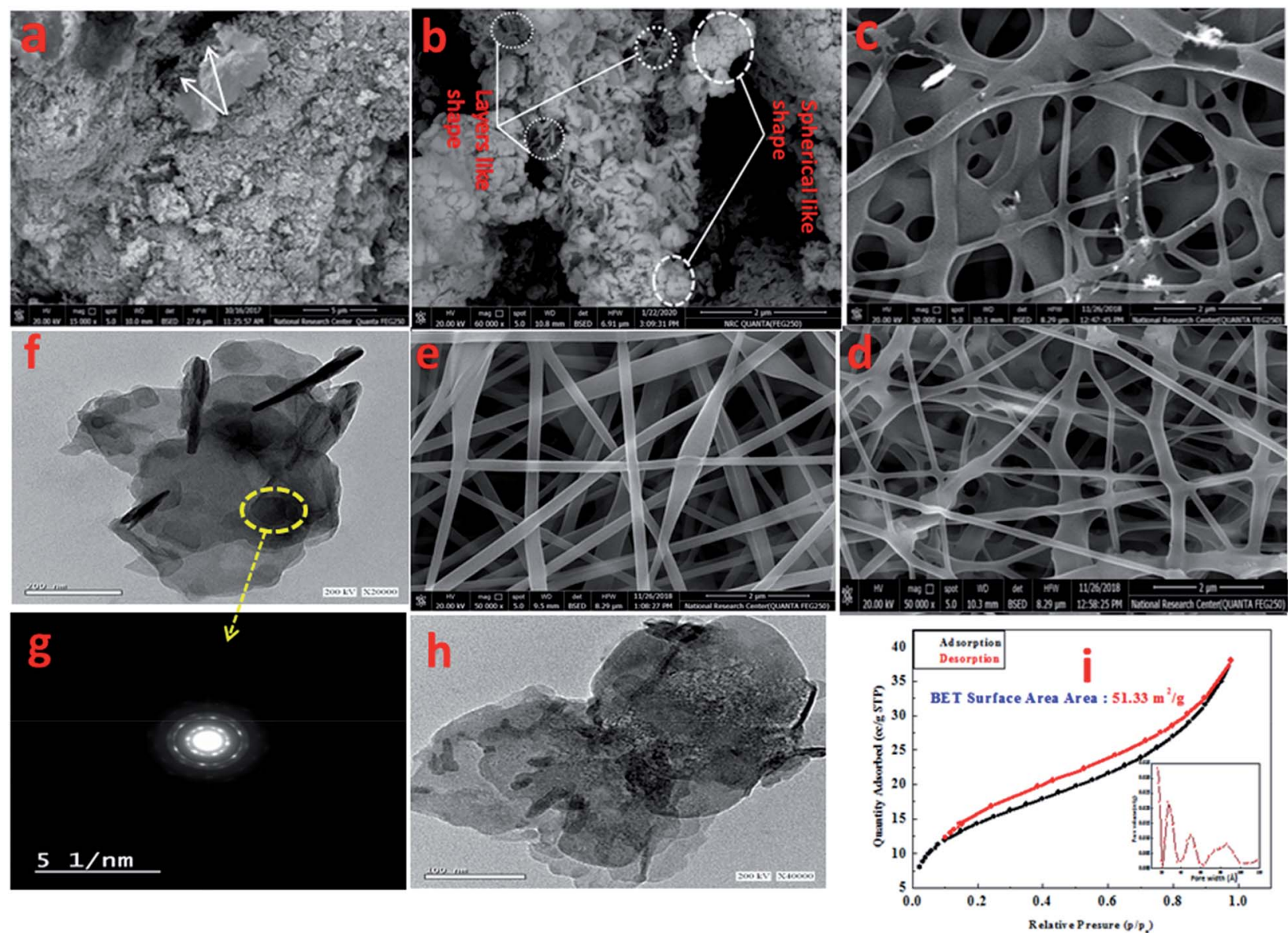

Fig. 3 FESEM images of (a) Zn-Al LDH, (b) Zn-Al LDH/cefotax, (c) PVA, (d) Zn-AL LDH@PVA, (e) Zn-Al LDH/cefotax@PVA. TEM images of (f) ZnAl LDH, SAED of Zn-Al LDH image (g), (h) Zn-Al LDH/cefotax and BET (surface area) of Zn-Al LDH/cefotax (i).

surface. The justification for this was the good hydrogen bonding interactions among the $(-\mathrm{OH})$ groups of $\mathrm{LDH}$, cefotax, and PVA, as per Scheme 1 imagined. These interactions and inorganic filling increased the viscosity and viscoelastic force, which affected the surface tension of the PVA solution and hampered it being electrospun. ${ }^{65}$ On the other hand, one can notice the obvious difference between the TEM image of the LDH displayed in Fig. $3 \mathrm{f}$ and that of $\mathrm{LDH} /$ cefotax in Fig. $3 \mathrm{~h}$. This divergence, especially, the visible roughness of the $\mathrm{LDH} /$ cefotax surface, referred to the interaction between LDH and cefotax.

3.1.4. Elemental composition, EDX, XRF, CHNS, and zeta potential analyses. It is worth highlighting that, to indicate the interaction between LDH and cefotax, it was necessary to identify the elemental constituents of the two entities. EDX analysis has now become common practice and is so practical that it is an essential part of SEM. The atomic weight percentages of all the samples were obtained from the elemental analysis. Fig. S1 $\uparrow$ displays the EDX spectra of: (a) $\mathrm{Zn}-\mathrm{Al} \mathrm{LDH}$ and (b) $\mathrm{Zn}-\mathrm{Al} \mathrm{LDH} /$ cefotax, indicating qualitative and quantitative characteristic peaks corresponding to all the different initial elements. The molecular formula as calculated was $\mathrm{Zn}_{0.9} \mathrm{Al}_{0.23}(-$ $\mathrm{OH})_{0.076}(\operatorname{cefotax})_{0.004}\left(\mathrm{H}_{2} \mathrm{O}\right)_{0.097} \mathrm{Cl}_{0.24}$, which matched with the XRF and thermal analysis, as reported in Table 2.
Concerning the aqueous stability of the prepared materials, the average hydrodynamic particle sizes of the suspended solution of $\mathrm{Zn}-\mathrm{Al} \mathrm{LDH}$ and $\mathrm{Zn}-\mathrm{Al} \mathrm{LDH} /$ cefotax were 304.3 and $318.6 \mathrm{~nm}$, respectively. The observed increase in the $\mathrm{Zn}-\mathrm{Al} \mathrm{LDH} /$ cefotax diameter was a result of the adsorption of cefotax on the LDH surface. Besides, the zeta potentials on the surface of $\mathrm{Zn}-$ Al LDH and $\mathrm{Zn}-\mathrm{Al} \mathrm{LDH/cefotax}$ were +28.4 and +15.9 , respectively. The decrease in zeta potential value reflected that cefotax was extensively obtained as a successful nanocomposite formulation, not only through hydrogen bonding as referred by FTIR but also via electrostatic interaction..$^{24,66}$

3.1.5. BET and TGA-DTA analyses. The surface area of LDH and $\mathrm{LDH} /$ cefotax were determined by the BET method. Fig. S3 $\uparrow$ shows the surface area measurement of $\mathrm{Zn}-\mathrm{Al} \mathrm{LDH}\left(40.65 \mathrm{~m}^{2}\right.$ $\mathrm{g}^{-1}$ ), whereby the pore diameter was determined using $\mathrm{BJH}$ analysis $(0.061 \mathrm{~nm})$ with a total pore volume of $0.056 \mathrm{~cm}^{3} \mathrm{~g}^{-1}$; here, there was a significant increase in the adsorption at a relative pressure of $p / p_{0}>0.02$, which meant that the nitrogen uptake below $p / p_{0}=0.02$ was negligible and the micropores were blocked, indicating that Zn-AL LDH was a type IV (mesoporous solid), which was attributed to the particle aggregation. Fig. $3 \mathrm{i}$ revealed that the adsorption/desorption process of LDH/ cefotax belonged to hysteresis type-II; implying that the 
Table 2 D-spacing, surface parameters, and chemical compositions

\begin{tabular}{|c|c|c|c|c|c|}
\hline $\begin{array}{l}\text { Analytical } \\
\text { method }\end{array}$ & \multicolumn{2}{|l|}{ wt $\%$} & Cefotax weight ${ }^{b} \%$ & $\mathrm{Zn}-\mathrm{Al}^{a}\left(\mathrm{~mol} \mathrm{~mol}{ }^{-1}\right)$ & Chemical composition \\
\hline
\end{tabular}

distribution of the pore size and shape was not well defined, and the materials were considered as macro-porous materials, whereby the surface area measurement of $\mathrm{Zn}-\mathrm{Al} \mathrm{LDH/cefotax}$ $\left(51.33 \mathrm{~m}^{2} \mathrm{~g}^{-1}\right)$ increased, which in turn increased the active sites of LDH and the amount of the adsorbed cefotax; and hence, this improved the cefotax efficiency at the infected sites. However, the total pore volume and the average pore diameter were decreased compared with the $\mathrm{Zn}-\mathrm{Al} \mathrm{LDH}{ }^{67}$ These results matched with the FESEM results for $\mathrm{Zn}-\mathrm{Al} \mathrm{LDH} /$ cefotax, where extra spherical-like shapes appeared beside layer-like shapes (Fig. 3b).

Fig. 4 shows the thermogravimetric analysis curves (TGA/ DTA) for Zn-Al LDH and Zn-Al LDH/cefotax, which show the thermal decomposition behavior. In Fig. 4a, the first weight loss
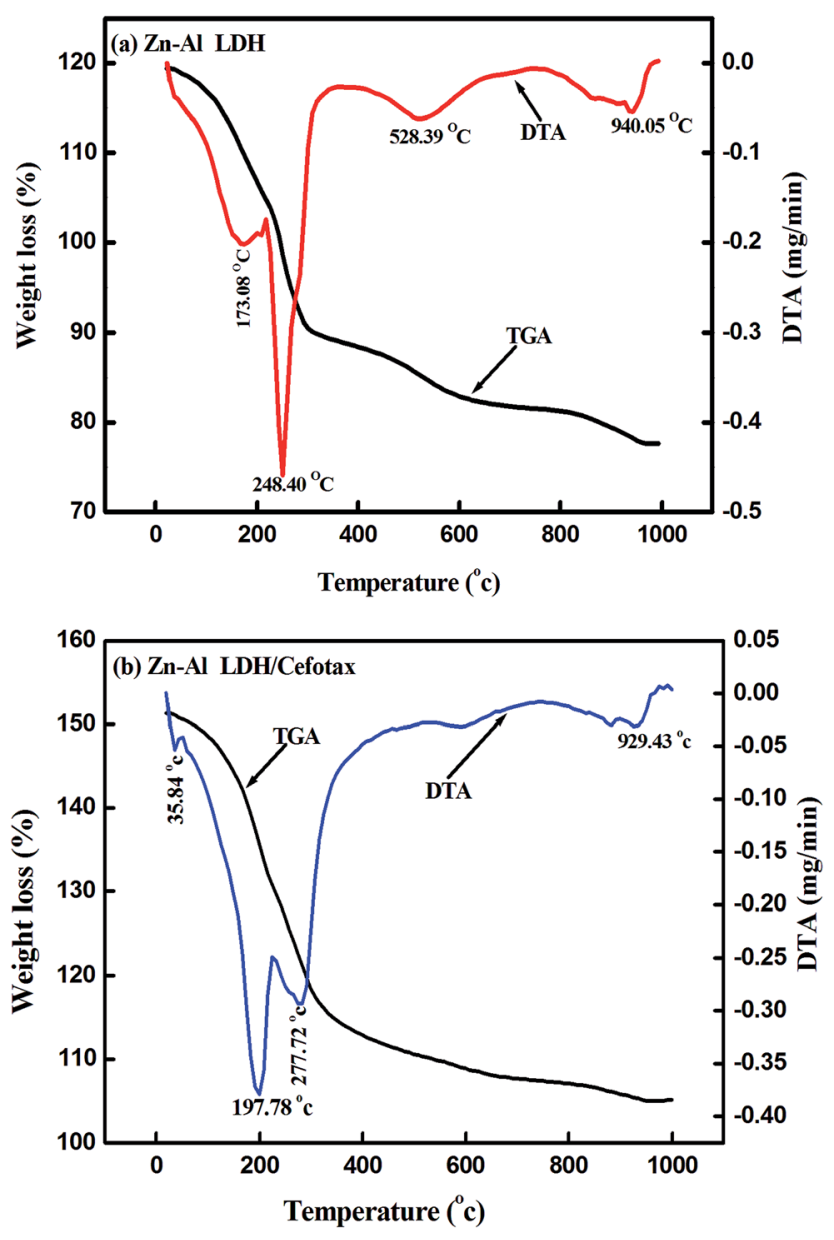

Fig. 4 TGA-DTA of (a) Zn-Al LDH, (b) Zn-Al LDH/cefotax. for $\mathrm{Zn}-\mathrm{Al} \mathrm{LDH}$ occurred from room temperature to $173.08^{\circ} \mathrm{C}$, corresponding to the adsorbed water $(1.75 \mathrm{mg})$. A mass loss of $1.30 \mathrm{mg}$ then took place in the temperature range to $248.40^{\circ} \mathrm{C}$, attributed to the dehydroxylation of the brucite-like layers. ${ }^{68}$ The decomposition of the brucite-like layer of chlorides occurred at $538.39{ }^{\circ} \mathrm{C}$ and the loss was $0.86 \mathrm{mg}$. The total weight lost at $970{ }^{\circ} \mathrm{C}$ was $41.20 \%$.

As shown in Fig. 4b presenting the TGA/DTA curves for Zn-Al $\mathrm{LDH} /$ cefotax, the two consecutive endothermic peaks marked at $192{ }^{\circ} \mathrm{C}$ and $272.51{ }^{\circ} \mathrm{C}$ are related to the removal of the interlayered water and dehydroxylation. There were further mass losses around $608^{\circ} \mathrm{C}$ and $929^{\circ} \mathrm{C}$ in the TGA/DTA curves, which were due to the combustion of the organic guest cefotax. The decomposition started at $192{ }^{\circ} \mathrm{C}$, suggesting the interaction of cefotax with $\mathrm{Zn}-\mathrm{Al}$ LDH through electrostatic attraction, hydrogen bonding, and van der Waals force, which reflect how the thermal stability of the $\mathrm{Zn}-\mathrm{Al} \mathrm{LDH-cefotax}$ nanocomposite was enhanced. The thermal analysis matched the FTIR analysis results.

3.1.6. Adsorption isotherm study. In the context of this research, an adsorption isotherm study was performed to describe the nature of the interaction between $\mathrm{Zn}-\mathrm{Al} \mathrm{LDH}$ and cefotax. The experimental data were fitted by various isotherm models, such as two-parameter isotherm models (Langmuir, ${ }^{69}$ Freundlich, ${ }^{70}$ Temkin $^{71}$ ), and three-parameter isotherm models (Langmuir-Freundlich, ${ }^{72}$ Sips ${ }^{73}$ Toth $^{74}$ ). The parameters of the included models are reported in Table 3.

Fig. 5a exhibits the experimental adsorption isotherms and shows the equilibrium adsorbed amount of cefotax on $\mathrm{Zn}-\mathrm{Al}$ LDH against cefotax equilibrium concentrations, with fitting the experimental data with the isotherm models. The error bars indicate the standard deviation of three experimental replications. Overall, it was evident that the acquired experimental data of the adsorption process could be fitted with the two- and three-parameters models. Freundlich and Toth models were the best fitting ( $R^{2}=0.983389$ and 0.98972 , respectively), as reported in Table 3.

3.1.7. Cefotax entrapment, release, and kinetics. Again, as aforementioned, the main limitation of cefotax in the clinical setting is the short half-life of cefotax, and so the main target of the current study was to sustain its release at the site of infection. As such, the current study considered the issues of drug load, release, and kinetics. The amount of the adsorbed cefotax at equilibrium $q_{\max }\left(\mathrm{mg} \mathrm{g}^{-1}\right)$ was calculated and the results reported in Table 3 as $19.8 \mathrm{mg} \mathrm{g}^{-1}$, and the calculated percentage of cefotax entrapment was $77.41 \%$ in the case of LDH/cefotax, and $67.83 \%$ for $\mathrm{LDH} /$ cefotax@PVA, which are equivalent to 
Table 3 Isotherm models and the measured parameters

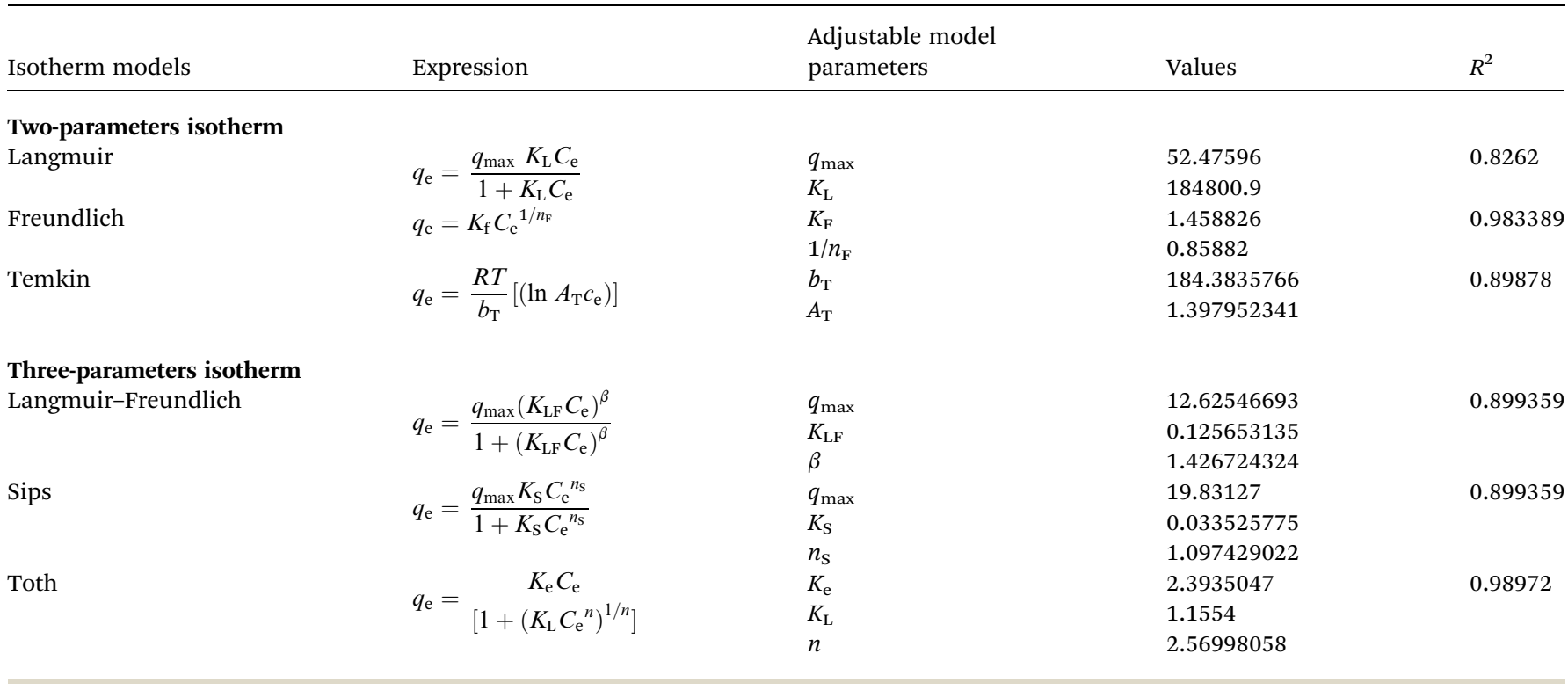
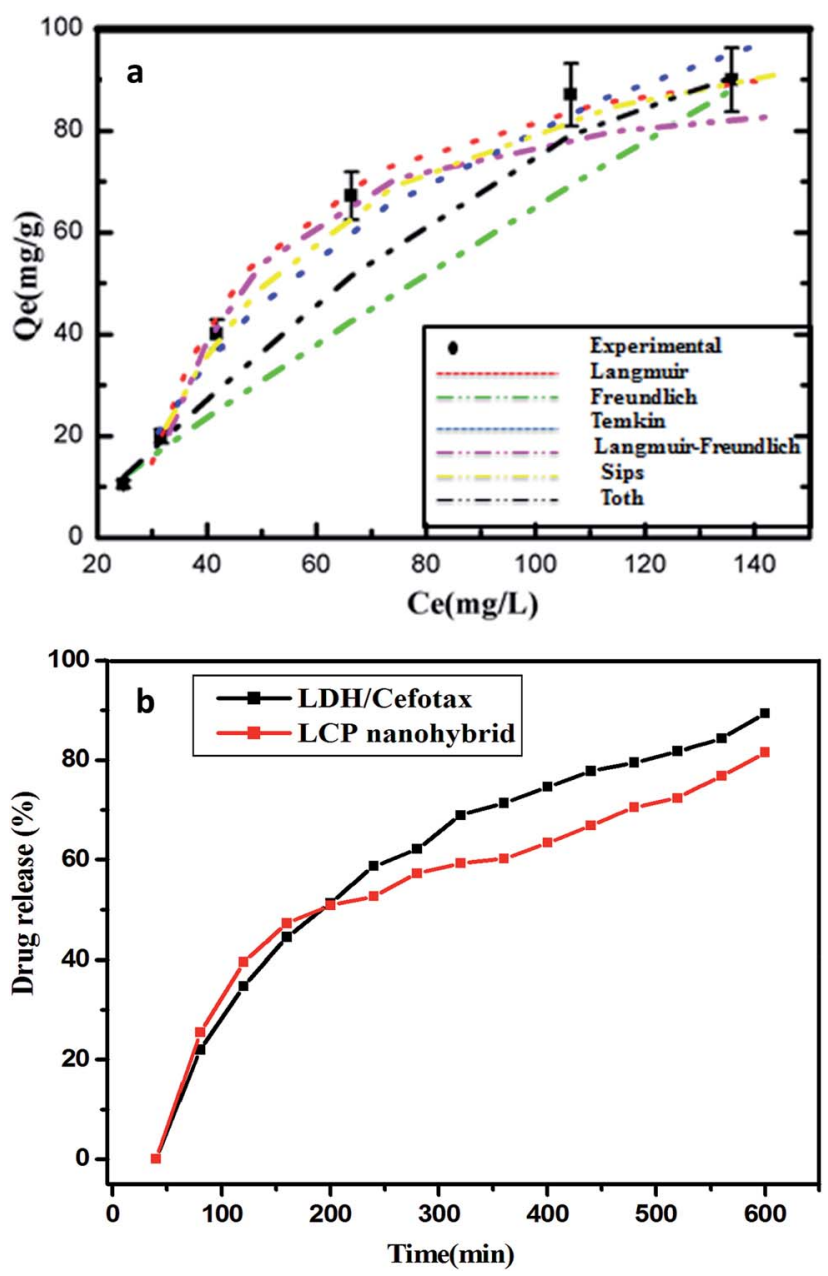

Fig. 5 (a) Fitting the experimental data with isotherm models, error bars indicate the standard deviation of three experimental replications, (b) drug release of cefotax from LDH/cefotax and LCP nanohybride.
$15.33 \mathrm{mg} \mathrm{g}^{-1}$, and $13.43 \mathrm{mg} \mathrm{g}^{-1}$ from the amount of the adsorbed cefotax at equilibrium $\left(19.8 \mathrm{mg} \mathrm{g}^{-1}\right)$, respectively. ${ }^{75}$ The decrease in the entrapment percentage of the LCP formula might be due to the loss of loosely bound cefotax on $\mathrm{LDH}$ (cefotax-LDH) during the formation of the LCP. ${ }^{42}$

In terms of cefotax release, Fig. $5 \mathrm{~b}$ displays the percentage of released cefotax from $\mathrm{LDH}$ and LCP against the interval time. In total, a sustained release of cefotax from LDH and LCP was attainable. It was shown that, from the start point, the release percentage of cefotax from $\mathrm{LDH}$ increased steadily; until it was about $89.31 \%$ after $600 \mathrm{~min}$ from the start point. At the same time, while the percentage from LCP rose dramatically higher than LDH until the 150th minute, it then started to decrease, and equaled that of $\mathrm{LDH}$ at the 200th minute, then increased again consistently; however, it was still lower than LDH and reached $81.55 \%$ at the endpoint. The idea of sustaining the release of cefotax and the noted difference between LDH and LCP was significantly dependent on the structure of the formula; whereby cefotax bound on the LDH surface either by weak hydrogen bonds or electrostatic force, which gave the chance for fast release compared to LCP; whereas the slow release in the LCP formula resulted from the restriction of cefotax between LDH and PVA. Indeed, the success of the sustained release achieved a significant and evident effect to help avoid burn wound infection.

Now, a question is raised as to how is cefotax released in each formula, i.e., LDH/cefotax, and LDH/cefotax@PVA? To answer this question, it was essential to study the release kinetics of the drug release rate using the first-order and parabolic models. Here, the drug-release profile of cefotax was fitted with the aforementioned equations. ${ }^{42}$

$$
\text { First-order model : } \log \left(\frac{X_{t}}{X_{0}}\right)=-k \mathrm{~d} t
$$

Parabolic diffusion mode $\left(1-X_{t} / X_{0}\right) / t=k-1 / 2+a$ 
where, $X_{0}$ and $X_{t}$ are the amounts of drug present in the mentioned formulas matrix at a release time of 0 and $t$, respectively, while $k$ and $k_{\mathrm{d}}$ are the overall release and apparent release constants. Mathew et al. ${ }^{76}$ stated that these models describe different physical processes. The first-order model describes a system where the release is dependent on the dissolution of the host material, while the parabolic model details a diffusion-controlled process.

The acquired results are shown in Fig. 6, which displays the time-dependent kinetic plots of the two models with the evaluated linear correlation coefficients $\left(R^{2}\right)$. Fig. 6a represents the first-order model plot for LDH/cefotax@PVA with $R^{2}=0.8093$, while Fig. $6 \mathrm{~b}$ is the parabolic model plot with $R^{2}=0.9953$. Fig. 6c presents the first-order model plot for LDH/cefotax $\left(R^{2}=\right.$ 0.9484), and Fig. 6d presents the parabolic model plot with $R^{2}=$ 0.9939. Consequently, for LDH/cefotax@PVA, the release could be well fitted with the parabolic model, implying that the cefotax release was based on a diffusion method. For LDH/ cefotax, the release fitted with the two models, but more with the parabolic, indicating that two physical processes could control the release, i.e., diffusion with the parabolic model and dissolution of cefotax from the surface of LDH with the firstorder model.

Overall, the presented results suggested that the release of cefotax from the LCP nanohybrid and $\mathrm{Zn}-\mathrm{Al} \mathrm{LDH}$ both involved dissolution up to $280 \mathrm{~min}$, when most of the surface cefotax was dissolved in the medium solution and then the diffusion controlled model took over after $280 \mathrm{~min}$. Cefotax diffusion occurs through intraparticle diffusion by anion exchange and by dissolution of the brucite layers. In addition, it is worth noting that the calculated $\mathrm{kd}$ of LDH/cefotax@PVA (525.56) was lower than that of $\mathrm{LDH} /$ cefotax (607.13), because of the compact and strong interactions between cefotax, $\mathrm{LDH}$, and PVA in the LCP nanohybride, which in turn slowed and sustained the release, as shown in the accumulative release profile (Fig. 5b).

\subsubsection{In vivo experiments}

3.1.8.1. Body weight, wound healing activity, and histopathology. Fig. 7A is a bar chart that displays the averages of the initial and the final averages of the body weights among the treatment groups. In general, a difference was noted but nonsignificant. In contrast, an evident divergence was observed in each group, in the order as follows: G4 (Grotto), G1 (Mat/LDH/ Cefotax MLC), G5 (Standard MEBO ointment), G2 (Mat/LDH), G6 (Control negative - Vaseline only), and G3, (Mat only). All the treated animals showed no inflammation or signs of toxicity, as reported in Table 4 . Fig. $7 \mathrm{~B}$ is a chart presenting the wound sizes of the induced burns treated with different materials at different interval days $(4,8,12,16$, and 21). The measurements of the experimental data are reported in Table 5. In total, the wound sizes differed among the groups along with
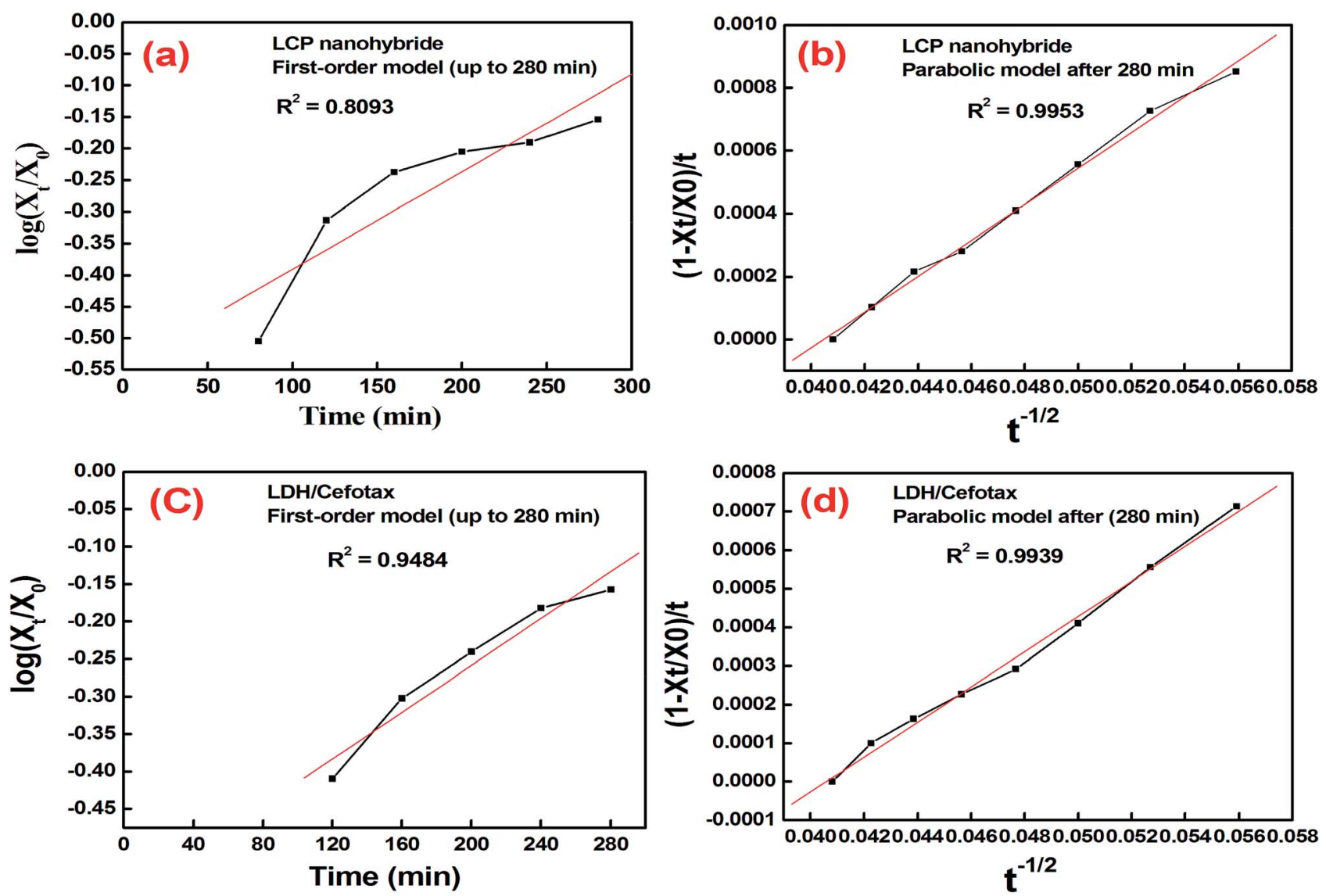

Fig. 6 Time-dependent kinetic plots of the two models: first-order $(a, c)$ and parabolic models $(b, d)$ with the evaluated linear correlation coefficients $\left(R^{2}\right)$. 

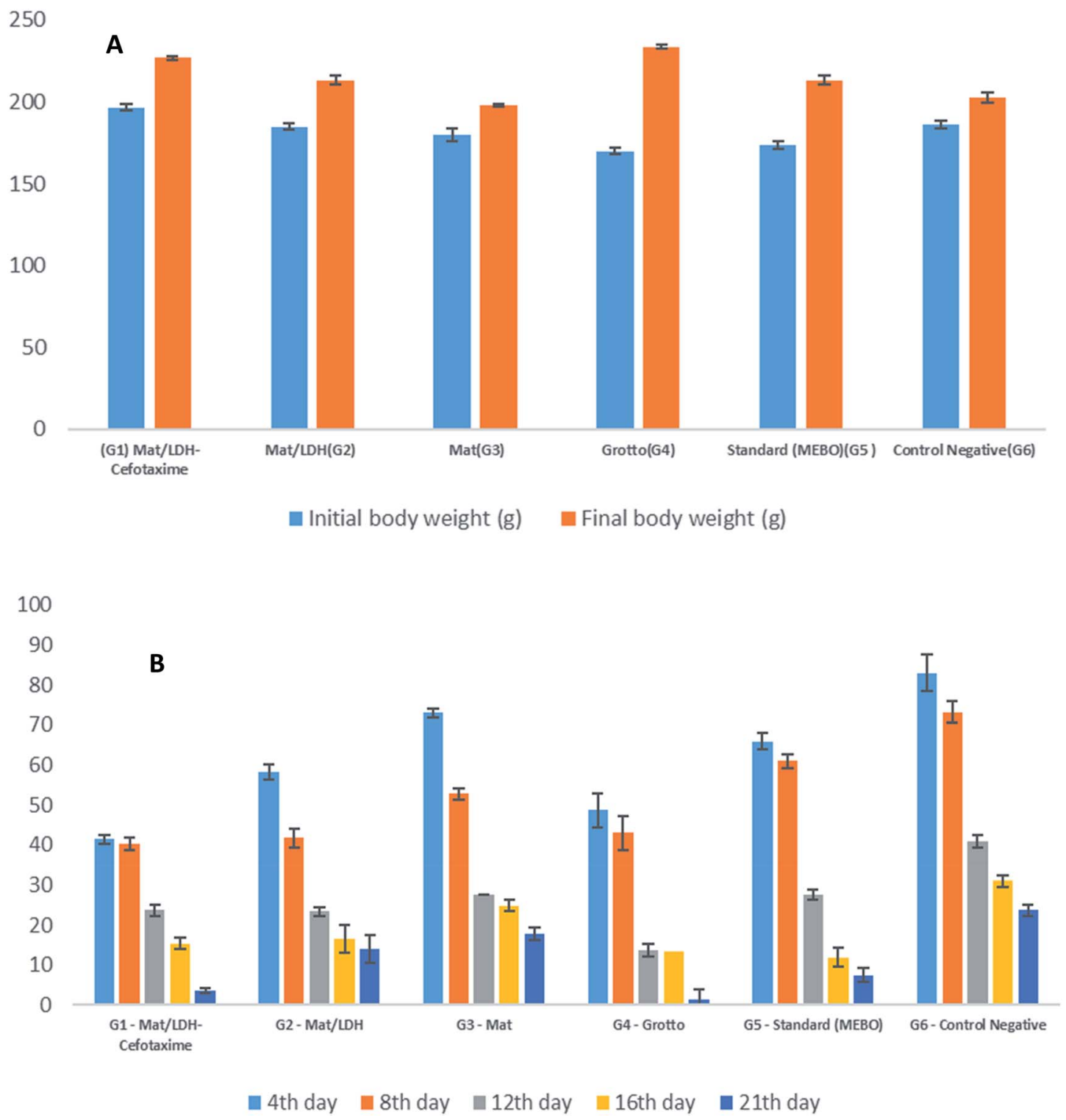

Fig. 7 (A) Effects of different treatments on the rat's body weight. (B) Wound-healing activity of the burn by different nanomaterials in rats ( $n=5$ ).

the days of treatment. However, G4 (Grotto) was the best, followed by G1 (Mat/LDH/Cefotax), G2 (Mat/LDH), G5 standard (MEBO) ointment, G3 (MAT only), and G6 (control group).

The macroscopic and morphological alterations are demonstrated in Fig. 8A. Besides, Fig. $8 \mathrm{~B}$ reveals the results from the histopathology. G4 (Grotto) and G1 (Mat/LDHCefotaxime) showed a complete healing of the epithelial layer with normal vasculature and cellular infiltration, while G2 (Mat/ $\mathrm{LDH}$ ) formed a normal epithelial layer with incomplete healing of the derm layer, and G3 (MAT only) and G6 (control group)

Table 4 Effects of different treatments on the rat's body weight and signs of toxicity ${ }^{a}$

\begin{tabular}{|c|c|c|c|c|c|}
\hline Group & Initial body weight (g) & Final body weight (g) & Weight gain (\%) & Total deaths & Signs of toxicity \\
\hline G1 Mat/LDH-cefotaxime & $196.75 \pm 2.1$ & $226.75 \pm 1.4$ & 15.30 & 0 & Nil \\
\hline G2 Mat/LDH & $185.00 \pm 2.2$ & $213.25 \pm 2.5$ & 15.13 & 0 & Nil \\
\hline G3 Mat & $180.005 \pm 3.7$ & $198.00 \pm 1.1$ & 10 & 0 & Nil \\
\hline G4 Grotto & $170.00 \pm 1.7$ & $233.75 \pm 1.4$ & 37.05 & 0 & Nil \\
\hline G5 standard (MEBO) & $173.75 \pm 2.3$ & $213.00 \pm 2.7$ & 23.12 & 0 & Nil \\
\hline G6 control negative & $186.25 \pm 2.7$ & $203.00 \pm 3.2$ & 9.13 & 0 & Nil \\
\hline
\end{tabular}

${ }^{a}$ Values represent the mean \pm SE of 5 animals in each group. 
exhibited discontinuity of the epidermal layer with granulation tissue in the derm layer, inflammatory cells with few capillaries, mild hemorrhage, and temperate necrotic foci; finally, the G5 standard (MEBO) ointment manifested incomplete formation of the epithelial layer and fixation on the derm layer.

It is important to realize that the antimicrobial activity of the tested materials is the key to wound healing with high efficiency, and to achieving this in a shorter time than normal. For instance, Grotto ointment contains important active ingredients, like vitamin E, bees wax, glycerin, allantoin, D-panthenol, lavender oil, and dimethicone. Fratini and co-workers [2016] mentioned that bees wax has antimicrobial activity. ${ }^{77}$ Likewise, in a major advanced study, Bano et al. demonstrated the antimicrobial effectiveness of PVA and its ability to facilitate the reepithelialization of injured tissues, whereby the wound closure rate reached more than $96 \% .^{78}$ Additionally, an increasing number of studies [Koosha et al., 2015; Sundaramurthi et al., 2012] have found that the incorporation of PVA into nanofibers enhances the gene expression of fibroblasts cells and increases its viability besides improving the electrospun membranes biocompatibility. ${ }^{79,80}$ On the other hand, it has now been shown that zinc nanoparticles have antimicrobial activity; besides a role in improving collagen deposition, enhancing the angiogenesis, proliferating the fibroblast, and helping the fast closure of wounds. ${ }^{81,82}$

In light of the mentioned aspects, the authors of the present study were encouraged to inspect the antimicrobial efficacy of the aforementioned materials. As mentioned above, the antimicrobial activity tests were conducted through MIC, MBC, and disc diffusion assay. Fig. 9I displays different plates with various strains of bacteria as Gram-positive and Gram-negative. In addition, the figure shows the inhibition zone of each strain with varying concentrations of the materials. The inhibition zone was measured in mm by the Agar diffusion method. As such, Fig. 9II is a bar chart illustrating the calculated mean of the inhibition zone ( $\mathrm{mm}$ ) on the $Y$-axis at different concentrations versus the diverse species of bacteria as mentioned above on the $X$-axis. Overall, the results reported that all the tested nanomaterials were effective against both Gram-positive and Gram-negative microorganisms, but the impact degree was different among the microorganisms.

As in the following examples, the diameter of the inhibition zone against Gram-negative bacteria was higher than against Gram-positive bacteria. The strongest activity was against $E$. coli (23.5 $\mathrm{mm})$, followed by S. aureus $(17.5 \mathrm{~mm})$, B. Subtilis $(17.5$ $\mathrm{mm})$, and $P$. aeruginosa $(15.5 \mathrm{~mm})$. It is important to highlight that, also the impact degree was different among the materials: $\mathrm{Mat} / \mathrm{LDH} /$ cefotax showed excellent activity with the largest zone of inhibition followed by the $\mathrm{LDH} /$ cefotax, cefotax alone, and PVA as a Mat only, while $\mathrm{Zn}-\mathrm{Al}$ LDH offered mild antimicrobial activity against both Gram-positive and Gram-negative bacteria.

It should be noted that the MIC and MBC of the investigated cefotax and cefotax-Zn/Al LDH versus Gram-positive and Gramnegative bacteria are shown in Fig. 10. Actually, the figure reveals that the recorded values of MIC and MBC of the cefotax and cefotax-Zn/Al LDH were significantly distinct from one species to another; aside from the MIC and MBC of the cefotax 

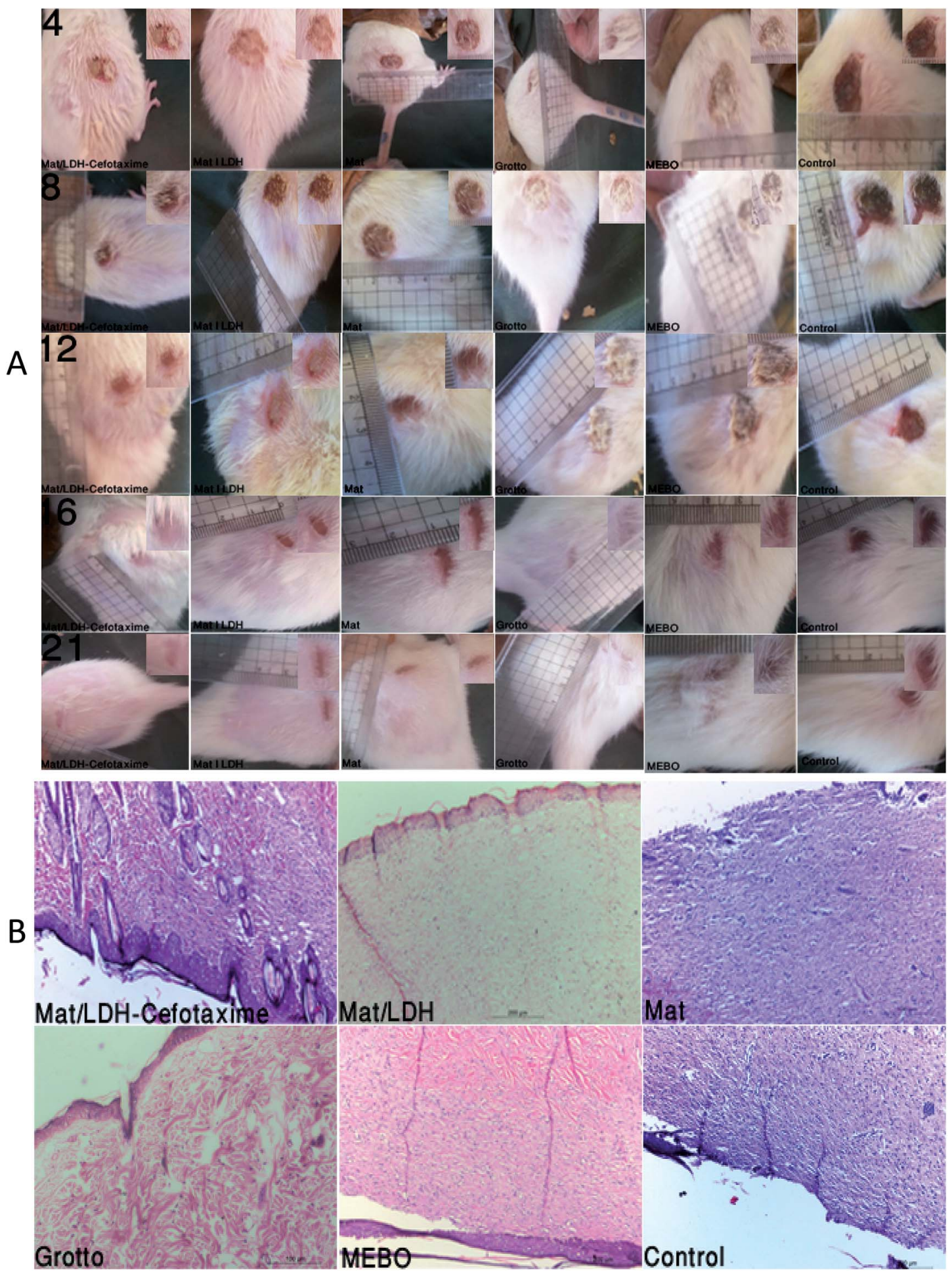

Fig. 8 (A) Wound-healing activity of G1 (MAT, LDH-cefotaxime), G2 (MAT/LDH), G3 (MAT), G4 (Grotto), G5 (MEBO), G6 (Control Negative) in rats $(n=5)$, at zero, $4,8,12,16$ and 21 days of treatment, (B) histopathological investigation of the different treatments on the burnt skin.

being higher than cefotax-Zn/Al LDH in both species. In addition, the significant difference in MIC between cefotax and cefotax-Zn/Al LDH was high in the Gram-positive bacteria compared to the Gram-negative bacteria, while the MBC was in contrast.
Indeed, destroying pathogenic microorganisms using antimicrobial agents is still a mysterious issue; because many factors affect the process, with the most important being the structure of the agent and that of the microbe. Cefotax is a thirdgeneration cephalosporin family of medications and works by interfering with the bacteria's cell wall. Cefotaxime is a $\beta$-lactam 

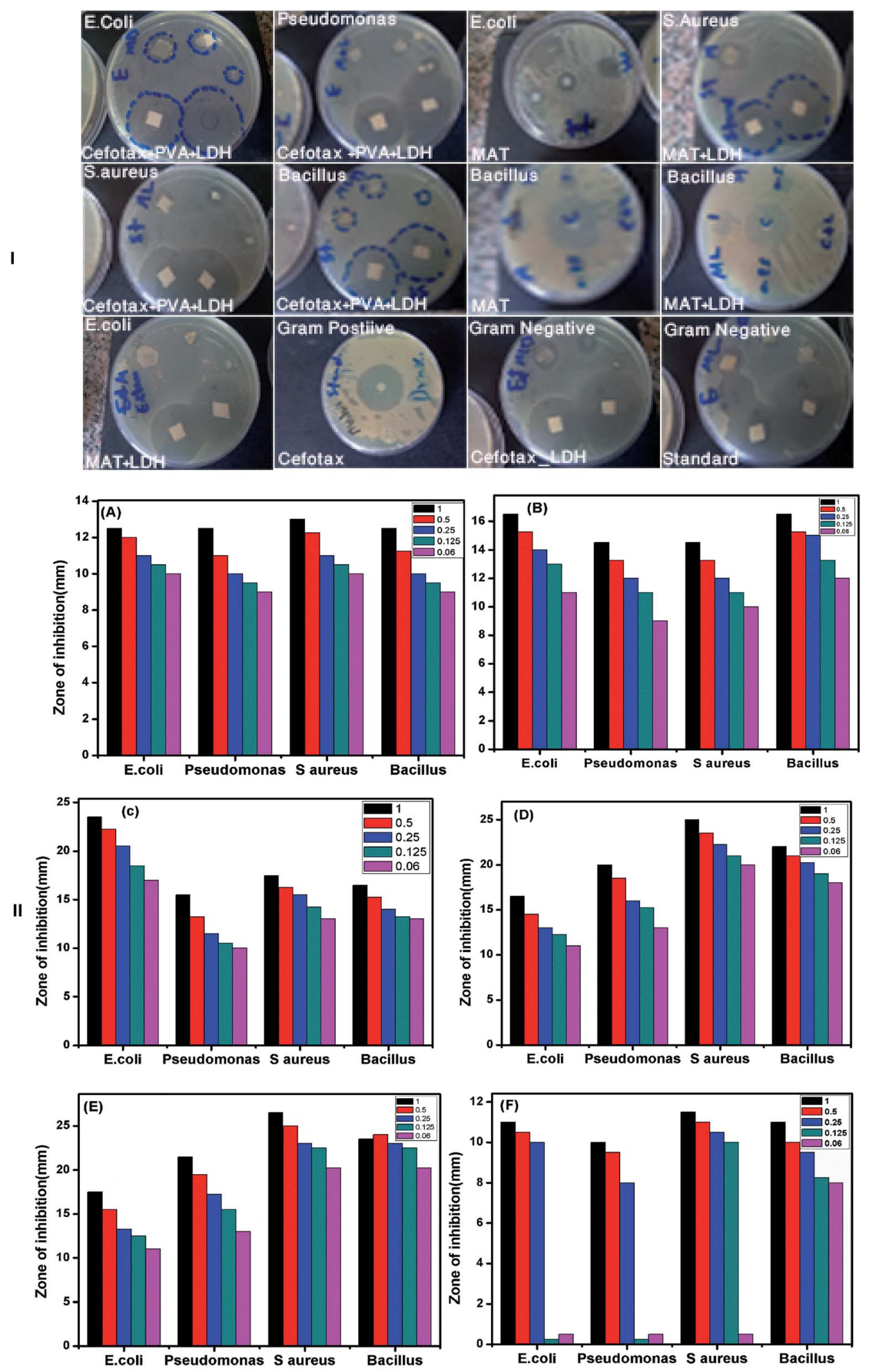

Fig. 9 (I) Plates with zones of inhibition against different bacterial strains and at different sizes of the nanomaterials, (II) different zones of inhibition against different bacterial strains and at different sizes of the nanomaterials (A) PVA, (B) LDH(APVA, (C) LDH/cefotax@PVA, (D) cefotax, (E) LDH/cefotax, and (F) LDH. 

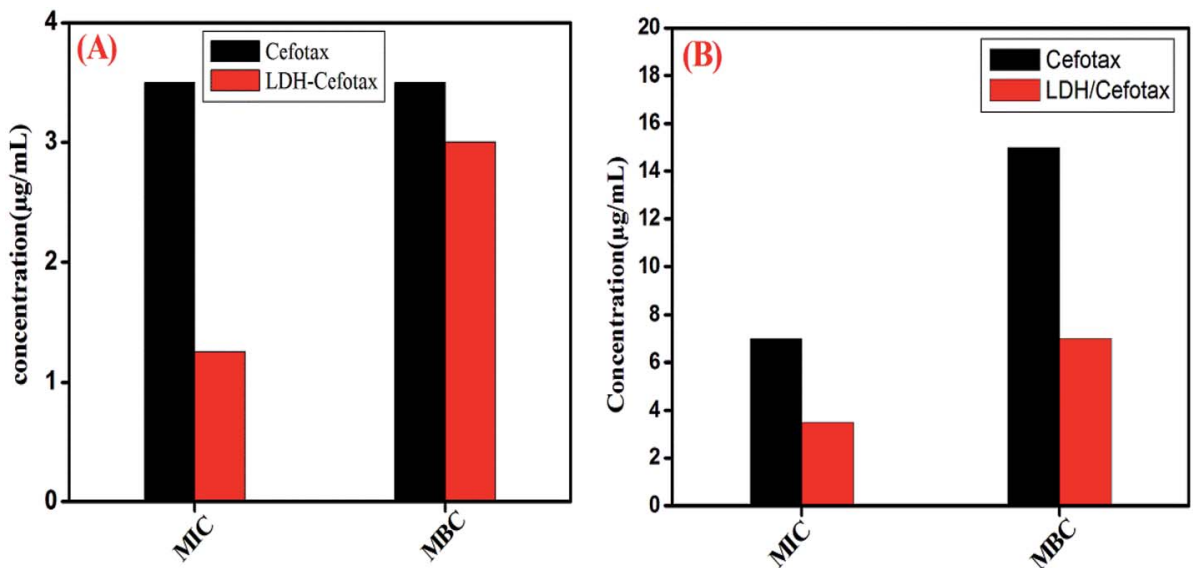

Fig. 10 MIC and MBC of both cefotax and cefotax-LDH against (A) Gram positive, and (B) Gram negative bacteria.

antibiotic, which inhibits bacterial cell wall synthesis by binding to one or more of the penicillin-binding proteins (PBPs). This inhibits the final transpeptidation step of peptidoglycan synthesis in bacterial cell walls, thus inhibiting cell wall biosynthesis. The current study expected the formation of reactive oxygen species (ROS), which would be able to destroy the phospholipid layer of the cell membrane and damage DNA/ RNA and proteins; the sources of the ROS were the metals of the $\mathrm{LDH}$, whereby $\mathrm{Zn}$ in the $\mathrm{LDH}$ played an essential role in accelerating the wound healing. ${ }^{83}$

To conclude, it is worth remembering that burn wound infection is a crucial issue, and the clinical setting of cefotax is limited. The standing study succeeded to formulate, characterize, and investigate cefotax release and kinetics, and to compare cetofax among the aforementioned materials as antibacterial agents. On the whole, the formulas of $\mathrm{LDH} /$ cefotax and LDH/cefotax@PVA managed to achieve a sustained release of cefotax without any significant burst release at the site of infection and showed enhanced efficacy compared to the cefotax alone. For that reason, we can say that LDH and PVA nanofibers are good cefotax carriers with a high entrapment capacity and ability to sustain its release over considerable time. In closing, the study encourages investigating this formula in humans. Whatever the clinical stage of the patient or disease, with its use we will be able to maintain high constant levels of cefotax because of its improved pharmacokinetics behavior; and as a result, the dosage will be more easily improved, and the dosing intervals could be expanded.

\section{Funding}

The present study was supported by individual funding.

\section{Consent for publication}

The authors consent this manuscript for publication.

\section{Availability of data and material}

The authors emphasize the availability of data and materials.

\section{Ethics approval and consent to participate}

The authors followed the ethics of research, approved and consented to participate in this study.

\section{Conflicts of interest}

The authors confirm no competing interests.

\section{Acknowledgements}

The authors are thankful to all members of the Materials Science and Nanotechnology Dept., Faculty of Postgraduate Studies for Advanced Sciences (PSAS), Beni-Suef University Egypt for supporting the preparation of the nanomaterials.

\section{References}

1 H. Liu, C. Wang, C. Li, Y. Qin, Z. Wang, F. Yang, Z. Li and J. Wang, A functional chitosan-based hydrogel as a wound dressing and drug delivery system in the treatment of wound healing, RSC Adv. , 2018, 8, 7533-7549.

2 M. Vignoni, H. de Alwis Weerasekera, M. J. Simpson, J. Phopase, T.-F. Mah, M. Griffith, E. I. Alarcon and J. C. Scaiano, LL37 peptide@silver nanoparticles: combining the best of the two worlds for skin infection control, Nanoscale, 2014, 6, 5725-5728.

3 G. Jin, M. P. Prabhakaran, D. Kai, S. K. Annamalai, K. D. Arunachalam and S. Ramakrishna, Tissue engineered plant extracts as nanofibrous wound dressing, Biomaterials, 2013, 34, 724-734.

4 S. Chen, B. Liu, M. A. Carlson, A. F. Gombart, D. A. Reilly and J. Xie, Recent advances in electrospun nanofibers for wound healing, Nanomedicine, 2017, 12, 1335-1352.

5 R. Bahramsoltani, M. H. Farzaei and R. Rahimi, Medicinal plants and their natural components as future drugs for the treatment of burn wounds: an integrative review, Arch. Dermatol. Res., 2014, 306, 601-617. 
6 L. Zhao, K. Wang, W. Li, T. Soteyome, H. Xiao and Z. Hu, Protective effects of polyphenolic extracts from longan seeds promote healing of deep second-degree burn in mice, Food Funct., 2019, 10, 1433-1443.

7 E. Nasiri, S. J. Hosseinimehr, A. Z. Hosseinzadeh, M. Azadbakht, J. Akbari and M. Azadbakht, The effects of Arnebia euchroma ointment on second-degree burn wounds: a randomized clinical trial, J. Ethnopharmacol., 2016, 189, 107-116.

8 V. Andreu, G. Mendoza, M. Arruebo and S. Irusta, Smart dressings based on nanostructured fibers containing natural origin antimicrobial, anti-inflammatory, and regenerative compounds, Materials, 2015, 8, 5154-5193.

9 S. Kalita, R. Kandimalla, B. Devi, B. Kalita, K. Kalita, M. Deka, A. C. Kataki, A. Sharma and J. Kotoky, Dual delivery of chloramphenicol and essential oil by poly- $\varepsilon$-caprolactonePluronic nanocapsules to treat MRSA-Candida co-infected chronic burn wounds, RSC Adv., 2017, 7, 1749-1758.

$10 \mathrm{H}$. Zhang, J. Wang, Y. Chen and Q. Nie, Solubility of sodium cefotaxime in aqueous 2-propanol mixtures, J. Chem. Eng. Data, 2006, 51, 2239-2241.

11 L. O. Gentry, Cefotaxime and prophylaxis: new approaches with a proven agent, Am. J. Med., 1990, 88, S32-S37.

12 J. K. Raddatz, B. E. Ostergaard and J. C. Rotschafer, Therapeutic options for cefotaxime in the management of bacterial infections, Diagn. Microbiol. Infect. Dis., 1995, 22, 77-83.

13 P. Saikia, A. Borah and R. L. Goswamee, Hybrid nanocomposites of layered double hydroxides: an update of their biological applications and future prospects, Colloid Polym. Sci., 2017, 295, 725-747.

14 H. Panda, R. Srivastava and D. Bahadur, Intercalation of hexacyanoferrate (III) ions in layered double hydroxides: a novel precursor to form ferri-/antiferromagnetic exchange coupled oxides and monodisperse nanograin spinel ferrites, J. Phys. Chem. C, 2009, 113, 9560-9567.

$15 \mathrm{M}$. Ardanuy and J. Velasco, $\mathrm{Mg}-\mathrm{Al}$ Layered double hydroxide nanoparticles: Evaluation of the thermal stability in polypropylene matrix, Appl. Clay Sci., 2011, 51, 341-347.

16 V. Rives, M. del Arco and C. Martín, Intercalation of drugs in layered double hydroxides and their controlled release: a review, Appl. Clay Sci., 2014, 88, 239-269.

17 G. Choi, H. Piao, Z. A. Alothman, A. Vinu, C.-O. Yun and J.-H. Choy, Anionic clay as the drug delivery vehicle: tumor targeting function of layered double hydroxidemethotrexate nanohybrid in C33A orthotopic cervical cancer model, Int. J. Nanomed., 2016, 11, 337.

18 N. A. Lopez, C. V. Luengo and M. J. Avena, Uptake/release of vancomycin on/from $\mathrm{Mg}-\mathrm{Al}$ layered double hydroxides, Adsorption, 2019, 25, 1349-1360.

19 L. A. de Sousa Rodrigues, A. Figueiras, F. Veiga, R. M. de Freitas, L. C. C. Nunes, E. C. da Silva Filho and C. M. da Silva Leite, The systems containing clays and clay minerals from modified drug release: a review, Colloids Surf., B, 2013, 103, 642-651.

20 V. Rives, M. del Arco and C. Martín, Layered double hydroxides as drug carriers and for controlled release of non-steroidal antiinflammatory drugs (NSAIDs): a review, $J$. Controlled Release, 2013, 169, 28-39.

21 A. Nagaraja, M. D. Jalageri, Y. M. Puttaiahgowda, K. R. Reddy and A. V. Raghu, A review on various maleic anhydride antimicrobial polymers, J. Microbiol. Methods, 2019, 105650.

22 S. B. Patil, S. Z. Inamdar, K. R. Reddy, A. V. Raghu, S. K. Soni and R. V. Kulkarni, Novel biocompatible poly (acrylamide)grafted-dextran hydrogels: Synthesis, characterization and biomedical applications, J. Microbiol. Methods, 2019, 159, 200-210.

23 A. Chatterjee, P. Bharadiya and D. Hansora, Layered double hydroxide based bionanocomposites, Appl. Clay Sci., 2019, 177, 19-36.

24 F. I. A. El-Ela, A. A. Farghali, R. K. Mahmoud, N. A. Mohamed and S. A. Moaty, New Approach in Ulcer Prevention and Wound Healing Treatment using Doxycycline and Amoxicillin/LDH Nanocomposites, Sci. Rep., 2019, 9, 1-15.

25 R. Ahmed, M. Tariq, I. Ali, R. Asghar, P. N. Khanam, R. Augustine and A. Hasan, Novel electrospun chitosan/ polyvinyl alcohol/zinc oxide nanofibrous mats with antibacterial and antioxidant properties for diabetic wound healing, Int. J. Biol. Macromol., 2018, 120, 385-393.

26 L. Mei, R. Fan, X. Li, Y. Wang, B. Han, Y. Gu, L. Zhou, Y. Zheng, A. Tong and G. Guo, Nanofibers for improving the wound repair process: the combination of a grafted chitosan and an antioxidant agent, Polym. Chem., 2017, 8, 1664-1671.

27 H. N. de Armas, E. Pardillo-Fontdevila and R. P. Hernández, Crystal and X-ray powder diffraction data for cefotaxime sodium salt, $\mathrm{C}_{16} \mathrm{H}_{16} \mathrm{~N}_{5} \mathrm{NaO}_{7} \mathrm{~S}_{2}$, Powder Diffr., 1999, 14, 142144.

28 V. J. Kumar, P. B. Gupta, K. Kumar, K. Rao, S. J. Prasanna, G. S. Kumar, H. K. Sharma and K. Mukkanti, Identification and characterization of new impurity in cefotaxime sodium drug substance, Der Pharma Chemica, 2010, 2, 230241.

29 F. J. Muhtadi and M. M. Hassan, Cefotaxime, Analytical Profiles of Drug Substances, Elsevier, 1982, pp. 139-168.

30 M. Aleksić, V. Savić, G. Popović, N. Burić and V. Kapetanović, Acidity constants of cefetamet, cefotaxime and ceftriaxone; the effect of the substituent at C3 position, J. Pharm. Biomed. Anal., 2005, 39, 752-756.

31 A. A. El-aziz, A. El-Maghraby and N. A. Taha, Comparison between polyvinyl alcohol (PVA) nanofiber and polyvinyl alcohol (PVA) nanofiber/hydroxyapatite (HA) for removal of $\mathrm{Zn}^{2+}$ ions from wastewater, Arabian J. Chem., 2017, 10, 1052-1060.

32 H. Chen, J. Lin, N. Zhang, L. Chen, S. Zhong, Y. Wang, W. Zhang and Q. Ling, Preparation of MgAl-EDTA-LDH based electrospun nanofiber membrane and its adsorption properties of copper(II) from wastewater, J. Hazard. Mater., 2018, 345, 1-9.

33 E. Z. Cai, C. H. Ang, A. Raju, K. B. Tan, E. C. H. Hing, Y. Loo, Y. C. Wong, H. Lee, J. Lim and S. M. Moochhala, Creation of consistent burn wounds: a rat model, Archives of Plastic Surgery, 2014, 41, 317. 
34 H. L. WALKER and A. D. MASON Jr, A standard animal burn, J. Trauma Acute Care Surg., 1968, 8, 1049-1051.

35 A. A. El-Shahawy, F. I. A. El-Ela, N. A. Mohamed, Z. E. Eldine and W. M. El Rouby, Synthesis and evaluation of layered double hydroxide/doxycycline and cobalt ferrite/chitosan nanohybrid efficacy on gram positive and gram negative bacteria, Mater. Sci. Eng., C, 2018, 91, 361-371.

36 F. Z. Mahjoubi, A. Khalidi, M. Abdennouri and N. Barka, ZnAl layered double hydroxides intercalated with carbonate, nitrate, chloride and sulphate ions: Synthesis, characterisation and dye removal properties, Journal of Taibah University for Science, 2017, 11, 90-100.

37 D. Mosangi, L. Moyo, S. K. Pillai and S. S. Ray, Acetyl salicylic acid-ZnAl layered double hydroxide functional nanohybrid for skin care application, RSC Adv., 2016, 6, 105862-105870.

38 E. Seftel, E. Popovici, M. Mertens, K. De Witte, G. Van Tendeloo, P. Cool and E. Vansant, Zn-Al layered double hydroxides: synthesis, characterization and photocatalytic application, Microporous Mesoporous Mater., 2008, 113, 296-304.

39 Y. Wong, H. M. Cooper, K. Zhang, M. Chen, P. Bartlett and Z. P. Xu, Efficiency of layered double hydroxide nanoparticle-mediated delivery of siRNA is determined by nucleotide sequence, J. Colloid Interface Sci., 2012, 369, 453-459.

40 S. Li, Y. Shen, M. Xiao, D. Liu, L. Fan and Z. Zhang, Simultaneous intercalation of 1-naphthylacetic acid and indole-3-butyric acid into layered double hydroxides and controlled release properties, J. Nanomater., 2014, 2014.

41 S. Li, Y. Shen, M. Xiao, D. Liu and L. Fan, Synthesis and controlled release properties of $\beta$-naphthoxyacetic acid intercalated $\mathrm{Mg}-\mathrm{Al}$ layered double hydroxides nanohybrids, Arabian J. Chem., 2019, 12(8), 2563-2571.

42 E. P. Komarala, S. Doshi, S. Thiyagarajan, M. Aslam and D. Bahadur, Studies on drug release kinetics and antibacterial activity against drug-resistant bacteria of cefotaxime sodium loaded layered double hydroxidefenugreek nanohybrid, New J. Chem., 2018, 42, 129-136.

43 G. George and M. P. Saravanakumar, Facile synthesis of carbon-coated layered double hydroxide and its comparative characterisation with $\mathrm{Zn}-\mathrm{Al} \mathrm{LDH}$ : application on crystal violet and malachite green dye adsorptionisotherm, kinetics and Box-Behnken design, Environ. Sci. Pollut. Res., 2018, 25, 30236-30254.

44 J. Liu, R. K. Yuen, Y. Hu, Tunable Properties of Exfoliated Polyvinylalcohol Nanocomposites by In Situ Coprecipitation of Layered Double Hydroxides, IOP Conference Series: Materials Science and Engineering, IOP Publishing, 2017, p. 012001.

45 M. Dinari and A. Nabiyan, Citric acid-modified layered double hydroxides as a green reinforcing agent for improving thermal and mechanical properties of poly(vinyl alcohol)-based nanocomposite films, Polym. Compos., 2017, 38, E128-E136.

46 S. Barik, L. Behera and S. K. Badamali, Assessment of thermal and antimicrobial properties of PAN/Zn-Al layered double hydroxide nanocomposites, Compos. Interfaces, 2017, 24, 579-591.

47 M. P. Bernardo and C. Ribeiro, [Mg-Al]-LDH and [Zn-Al]-LDH as Matrices for Removal of High Loadings of Phosphate, Mater. Res., 2018, 21.

48 M. Pérez, I. Pavlovic, C. Barriga, J. Cornejo, M. Hermosín and M. Ulibarri, Uptake of $\mathrm{Cu} 2+, \mathrm{Cd} 2+$ and $\mathrm{Pb} 2+$ on $\mathrm{Zn}-\mathrm{Al}$ layered double hydroxide intercalated with edta, Appl. Clay Sci., 2006, 32, 245-251.

49 G. Starukh, O. Rozovik and O. Oranska, Organo/Zn-Al LDH nanocomposites for cationic dye removal from aqueous media, Nanoscale Res. Lett., 2016, 11, 228.

50 S. Gunasekaran and J. Charles, Spectral Measurements and Qualitative Analysis of Ceftriaxone and Cefotaxime, Asian J. Chem., 2008, 20, 1343.

51 U. Habiba, T. A. Siddique, S. Talebian, J. J. L. Lee, A. Salleh, B. C. Ang and A. M. Afifi, Effect of deacetylation on property of electrospun chitosan/PVA nanofibrous membrane and removal of methyl orange, $\mathrm{Fe}$ (III) and $\mathrm{Cr}$ (VI) ions, Carbohydr. Polym., 2017, 177, 32-39.

52 S. Mallakpour and M. Hatami, LDH-VB9-TiO2 and LDH-VB9TiO2/crosslinked PVA nanocomposite prepared via facile and green technique and their photo-degradation application for methylene blue dye under ultraviolet illumination, Appl. Clay Sci., 2018, 163, 235-248.

53 R. A. Rebia, S. Rozet, Y. Tamada and T. Tanaka, Biodegradable PHBH/PVA blend nanofibers: Fabrication, characterization, in vitro degradation, and in vitro biocompatibility, Polym. Degrad. Stab., 2018, 154, 124-136.

54 H. S. Mansur, C. M. Sadahira, A. N. Souza and A. A. Mansur, FTIR spectroscopy characterization of poly (vinyl alcohol) hydrogel with different hydrolysis degree and chemically crosslinked with glutaraldehyde, Mater. Sci. Eng., C, 2008, 28, 539-548.

55 S. Y. Oh, D. I. Yoo, Y. Shin and G. Seo, FTIR analysis of cellulose treated with sodium hydroxide and carbon dioxide, Carbohydr. Res., 2005, 340, 417-428.

56 L.-P. Xiao, Z. Lin, W.-X. Peng, T.-Q. Yuan, F. Xu, N.-C. Li, Q.-S. Tao, H. Xiang and R.-C. Sun, Unraveling the structural characteristics of lignin in hydrothermal pretreated fibers and manufactured binderless boards from Eucalyptus grandis, Sustainable Chem. Processes, 2014, 2, 9.

57 M. J. Barnabas, S. Parambadath, A. Mathew, S. S. Park, A. Vinu and C.-S. Ha, Highly efficient and selective adsorption of In3+ on pristine $\mathrm{Zn} / \mathrm{Al}$ layered double hydroxide (Zn/Al-LDH) from aqueous solutions, J. Solid State Chem., 2016, 233, 133-142.

58 R. Santos, J. Tronto, V. Briois and C. Santilli, Thermal decomposition and recovery properties of $\mathrm{ZnAl}-\mathrm{CO} \quad 3$ layered double hydroxide for anionic dye adsorption: insight into the aggregative nucleation and growth mechanism of the LDH memory effect, J. Mater. Chem. A, 2017, 5, 9998-10009.

59 A. G. Destaye, C.-K. Lin and C.-K. Lee, Glutaraldehyde vapor cross-linked nanofibrous PVA mat with in situ formed silver 
nanoparticles, ACS Appl. Mater. Interfaces, 2013, 5, 47454752.

60 B. Dhandayuthapani, R. Mallampati, D. Sriramulu, R. F. Dsouza and S. Valiyaveettil, PVA/gluten hybrid nanofibers for removal of nanoparticles from water, ACS Sustainable Chem. Eng., 2014, 2, 1014-1021.

61 Q. Zhang, Q. Du, Y. Zhao, F. Chen, Z. Wang, Y. Zhang, H. Ni, H. Deng, Y. Li and Y. Chen, Graphene oxide-modified electrospun polyvinyl alcohol nanofibrous scaffolds with potential as skin wound dressings, $R S C A d v$., 2017, 7, 28826-28836.

62 M. S. Peresin, Y. Habibi, A.-H. Vesterinen, O. J. Rojas, J. J. Pawlak and J. V. Seppälä, Effect of moisture on electrospun nanofiber composites of poly (vinyl alcohol) and cellulose nanocrystals, Biomacromolecules, 2010, 11, 2471-2477.

63 M. S. Enayati, T. Behzad, P. Sajkiewicz, R. Bagheri, L. Ghasemi-Mobarakeh, S. Kuśnieruk, J. Rogowska-Tylman, Z. Pahlevanneshan, E. Choińska and W. Święszkowski, Fabrication and characterization of electrospun bionanocomposites of poly (vinyl alcohol)/ nanohydroxyapatite/cellulose nanofibers, Int. J. Polym. Mater. Polym. Biomater., 2016, 65, 660-674.

64 J. Si, Z. Cui, Q. Wang, Q. Liu and C. Liu, Biomimetic composite scaffolds based on mineralization of hydroxyapatite on electrospun poly ( $\varepsilon$-caprolactone)/ nanocellulose fibers, Carbohydr. Polym., 2016, 143, 270-278.

65 S. S. Homaeigohar and M. Elbahri, Novel compaction resistant and ductile nanocomposite nanofibrous microfiltration membranes, J. Colloid Interface Sci., 2012, 372, 6-15.

66 Y. Wong, K. Markham, Z. P. Xu, M. Chen, G. Q. M. Lu, P. F. Bartlett and H. M. Cooper, Efficient delivery of siRNA to cortical neurons using layered double hydroxide nanoparticles, Biomaterials, 2010, 31, 8770-8779.

67 H. A. Younes, R. Khaled, H. M. Mahmoud, H. F. Nassar, M. M. Abdelrahman, F. I. A. El-Ela and M. Taha, Computational and experimental studies on the efficient removal of diclofenac from water using ZnFe-layered double hydroxide as an environmentally benign absorbent, J. Taiwan Inst. Chem. Eng., 2019, 102, 297-311.

68 K. Parida, M. Sahoo and S. Singha, Synthesis and characterization of a Fe (III)-Schiff base complex in a $\mathrm{Zn}-\mathrm{Al}$ LDH host for cyclohexane oxidation, J. Mol. Catal. A: Chem., 2010, 329, 7-12.

69 N. Sivarajasekar and R. Baskar, Adsorption of basic red 9 onto activated carbon derived from immature cotton seeds: isotherm studies and error analysis, Desalin. Water Treat., 2014, 52, 7743-7765.

70 D. Balarak, F. Mostafapour, E. Bazrafshan and T. A. Saleh, Studies on the adsorption of amoxicillin on multi-wall carbon nanotubes, Water Sci. Technol., 2017, 75, 1599-1606.
71 R. Ding, P. Zhang, M. Seredych and T. J. Bandosz, Removal of antibiotics from water using sewage sludge-and waste oil sludge-derived adsorbents, Water Res., 2012, 46, 4081-4090.

72 G. P. Jeppu and T. P. Clement, A modified LangmuirFreundlich isotherm model for simulating $\mathrm{pH}$-dependent adsorption effects, J. Contam. Hydrol., 2012, 129, 46-53.

73 V. K. Upadhyayula, S. Deng, M. C. Mitchell and G. B. Smith, Application of carbon nanotube technology for removal of contaminants in drinking water: a review, Sci. Total Environ., 2009, 408, 1-13.

74 K. Vijayaraghavan, T. Padmesh, K. Palanivelu and M. Velan, Biosorption of nickel (II) ions onto Sargassum wightii: application of two-parameter and three-parameter isotherm models, J. Hazard. Mater., 2006, 133, 304-308.

75 D. P. Suhas, T. M. Aminabhavi and A. V. Raghu, Mixed matrix membranes of H-ZSM5-loaded poly (vinyl alcohol) used in pervaporation dehydration of alcohols: influence of silica/alumina ratio, Polym. Eng. Sci., 2014, 54, 1774-1782.

76 M. Joy, S. J. Iyengar, J. Chakraborty and S. Ghosh, Layered double hydroxide using hydrothermal treatment: morphology evolution, intercalation and release kinetics of diclofenac sodium, Frontiers of Materials Science, 2017, 11, 395-408.

77 F. Fratini, G. Cilia, B. Turchi and A. Felicioli, Beeswax: A minireview of its antimicrobial activity and its application in medicine, Asian Pac. J. Trop. Med., 2016, 9, 839-843.

78 I. Bano, M. Arshad, T. Yasin and M. A. Ghauri, Preparation, characterization and evaluation of glycerol plasticized chitosan/PVA blends for burn wounds, Int. J. Biol. Macromol., 2019, 124, 155-162.

79 M. Koosha and H. Mirzadeh, Electrospinning, mechanical properties, and cell behavior study of chitosan/PVA nanofibers, J. Biomed. Mater. Res., Part A, 2015, 103, 30813093.

80 D. Sundaramurthi, K. S. Vasanthan, P. Kuppan, U. M. Krishnan and S. Sethuraman, Electrospun nanostructured chitosan-poly (vinyl alcohol) scaffolds: a biomimetic extracellular matrix as dermal substitute, Biomed. Mater., 2012, 7, 045005.

81 R. Augustine, H. N. Malik, D. K. Singhal, A. Mukherjee, D. Malakar, N. Kalarikkal and S. Thomas, Electrospun polycaprolactone/Zno nanocomposite membranes as biomaterials with antibacterial and cell adhesion properties, J. Polym. Res., 2014, 21, 347.

82 P. V. Kulkarni, C. A. Roney, P. P. Antich, F. J. Bonte, A. V. Raghu and T. M. Aminabhavi, Quinoline-n-butylcyanoacrylate-based nanoparticles for brain targeting for the diagnosis of Alzheimer's disease, Wiley Interdiscip. Rev.: Nanomed. Nanobiotechnol., 2010, 2, 35-47.

83 W. M. Hosny and P. A. Khalaf-Alaa, Potentiometric study and biological activity of some metal ion complexes of polyvinyl alcohol (PVA), Int. J. Electrochem. Sci., 2013, 8, 1520-1533. 